$$
\begin{aligned}
& 10 \\
& \text { WORKING }
\end{aligned}
$$

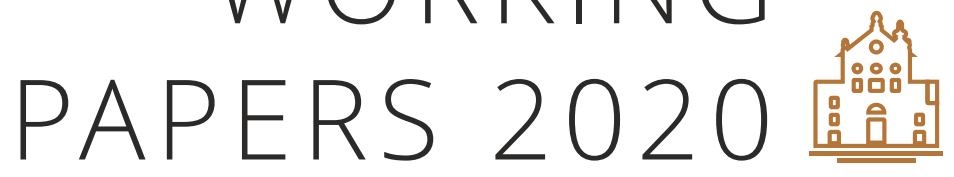

BANKS' COMPLEXITY ANDRISK:

AGENCY PROBLEMS AND

DIVERSIEICATION BENEFITS

Diana Bonfim / Sónia Felix 



\section{0 \\ WORKING PAPERS 2020}

\section{BANKS' COMPLEXITY AND RISK: \\ AGENCY PROBLEMS AND DIVERSIFICATION BENEFITS}

Diana Bonfim | Sónia Felix

JUNE 2020 The analyses, opinions and findings of these papers represent the views of the authors, they are not necessarily those of the Banco de Portugal or the Eurosystem

Please address correspondence to Banco de Portugal, Economics and Research Department Av. Almirante Reis, 71, 1150-012 Lisboa, Portugal Tel.: +351 213130 000, email: estudos@bportugal.pt

BANCO DE PORTUGAL EUROSYSTEM

Lisboa, 2020 • www.bportugal.pt 
Working Papers | Lisboa 2020 • Banco de Portugal Av. Almirante Reis, 71 | 1150-012 Lisboa • www.bportugal.pt • Edition Economics and Research Department • ISBN (online) 978-989-678-738-7 • ISSN (online) 2182-0422 


\title{
Banks' complexity and risk: agency problems and diversification benefits
}

\author{
Diana Bonfim \\ Banco de Portugal \\ Católica-Lisbon School of Business and \\ Economics
}

\author{
Sónia Félix \\ Banco de Portugal \\ Nova School of Business and Economics
}

June 2020

\begin{abstract}
Bank complexity is often associated with risk, due to moral hazard and agency problems. At the same time, complexity may be linked to diversification and scale economies, thus leading to less risk. In this paper, we provide empirical evidence on the relationship between bank complexity and risk-taking. We find a positive relationship between geographical complexity and bank risk. Banks that operate in more countries, both through banks and non-banks, have riskier balance sheets and more non-performing loans. Further, banks that operate in Africa have higher risk levels due to larger volatility of returns. The link between structural complexity and bank risk is weaker, but generally negative. Our results suggest that moral hazard and agency problems may be more acute when banks operate in many geographies and in emerging market economies. In contrast, the results are consistent with diversification and scale benefits arising from operating in more business areas.
\end{abstract}

JEL: F23, G21, G23

Keywords: bank complexity, risk-taking, diversification.

\footnotetext{
Acknowledgements: We would like to warmly thank Sónia Costa for her crucial contribution in many stages of this project and for her permanent support. We would like to thank the Banking Supervision Department for help with part of the data used in the project. We would like to thank comments and suggestions by Nuno Alves, António Antunes, Luísa Farinha, Ana Cristina Leal, Natalya Martynova (discussant), Vítor Oliveira, Maximiano Pinheiro, Pedro Santos, and Asani Sarkar (discussant). This paper is part of a coordinated cross-country research initiative of the International Banking Research Network (IBRN), with teams developing analytical tests and approaches to inform this complexity and risk topic. Bonfim acknowledges financial support from grants UID/GES/00407/2013 and PTDC/EGE-OGE/30314/2017 of the Portuguese Foundation for Science and Technology-FCT. The views expressed are those of the authors and are not necessarily those of Banco de Portugal or the Eurosystem.

E-mail: scfelix@bportugal.pt; dbonfim@bportugal.pt
} 


\section{Introduction}

Bank complexity is perceived today as something negative for financial stability. If a bank is too big, too opaque or too complex, monitoring it becomes much more challenging. One of the lessons of the global financial crisis was that the costs of living with the pervasive incentives facing too-big-to-fail banks could be too-big-to-fund using taxpayers' money. There were immediate calls to make sure that these large (and complex) institutions would internalize the costs they might impose on society through this too-big-to-fail problem. If banks become reckless in their decisions due to the belief that they will be bailed out in case of a bad outcome, then regulation should make sure that something breaks this costly moral hazard problem. Regulation has thus moved in the direction of providing incentives for banks to become smaller, more transparent, and simpler. This should allow supervisors to better perform their jobs, as well as for depositors and other investors to be more aware of the risks that they are exposed to.

Despite the regulatory changes, the link between banks' complexity and the risks they assume is not entirely clear. On the one hand, complexity may indeed have a dark side and be associated with risk-taking behaviors. More complex banks are more opaque and more difficult to manage and monitor, thus creating moral hazard and agency problems (Morgan 2002; Dam and Koetter 2012; Duchin and Sosyura 2014; Beck et al. 2017). Banks might also take too much risk because they believe that they are too big to fail (Acharya et al. 2016; Cetorelli and Traina 2018) or because of strategic complementarities (Farhi and Tirole 2012). On the other hand, complexity may be necessary to achieve a certain operating scale and thus be part of a bank's business model without entailing more risk-taking (Cetorelli et al. 2014; Cetorelli and Goldberg 2016). Complexity can be a different name for diversification, which has well established benefits in finance (Markowitz 1952; Laeven and Levine 2007; Buch et al. 2012; Berger et al. 2016).

Given the ambiguous predictions and findings in the literature, in this paper we empirically analyze the relationship between complexity and risk in banks. We consider two different concepts of bank complexity: geographical and structural. The former refers to the complexity that might arise from the fact that a banking group operates across many jurisdictions. The latter refers to the business structure of the banking group, taking into account its internal organization through affiliates and business types.

Using supervisory data on the activity and organization of Portuguese banking groups, we estimate the relationship between these two dimensions of bank complexity and bank risk. We consider several indicators of risk, to take on board different aspects of risk in the banking business.

We find that banks that are more exposed to geographical complexity have more risk. This positive relationship works through two channels. First, the number of countries in which a bank operates, both through bank and non-bank activities, is positively related with the riskiness of banks' assets. Second, activities in emerging markets increase banks' risk through income volatility. This result is anchored on 
the fact that the geographical exposure of Portuguese banks is based on two pillars: part of the cross-border activity refers to activity in other European countries, while another important part refers to activity in Africa, notably in former Portuguese colonies. The moral hazard and agency problems that explain a positive relationship between complexity and risk may assume a different magnitude when banks operate in countries that are very similar in terms of the legal, economic, governance, regulatory and supervisory framework, or when they operate in countries in which many of these dimensions may differ significantly. La Porta et al. (2000), Levine et al. (2000), Beck et al. (2006), and Correa and Goldberg (2019) discuss the importance of these differences in the activity of banks. Beck et al. (2011), Demirgüç-Kunt and Klapper (2012), Beck and Cull (2013), and Beck (2015) discuss in detail how banks operate in Africa and which challenges they face.

When it comes to structural complexity, the results are quite different. We find a negative relationship between structural complexity and bank risk. This is consistent with positive effects stemming from diversification and economies of scale.

That said, the results obtained for structural complexity are generally weaker than those obtained for geographical complexity. Risk seems to stem more from the fact that banks are exposed to multiple geographies than from complexity measures associated with their organizational structure and the reach of their activities in terms of business sectors.

One important concern underlying these results is that it is challenging to establish a causal relationship between complexity and risk. To mitigate endogeneity concerns arising from reverse causality and omitted variables, we explore one recent change in bank regulation that might affect banks' complexity, without necessarily directly affecting banks' risk. Systemically important institutions in each European country have to hold additional capital buffers, through the Other Systemically Important Institutions capital buffer (O-SII buffer). This buffer is calibrated by taking into account banks' size, their importance for the economy, their interconnection and, crucially, their complexity. As such, a bank that is subject to this buffer may have incentives to decrease its complexity (Carmassi and Herring 2016). We explore this exogenous change in regulation using an instrumental variables approach. The results differ in several aspects when we use this approach, but the most important conclusions remain valid. We confirm a positive and robust relationship between geographical complexity and banks' risk and we obtain (weaker) evidence of a negative relationship between structural complexity and risk.

Our paper contributes to the literature on banks' complexity and risk. This literature offers conflicting theoretical and empirical evidence on the relationship between these two variables. Our analysis helps to understand whether more complexity goes hand in hand with more risk, coming from agency problems and moral hazard (Farhi and Tirole 2012; Dam and Koetter 2012; Duchin and Sosyura 2014; Acharya et al. 2016; Chernobai et al. 2020; Beck et al. 2017), or if complexity is associated with diversification benefits, enhanced performance and risk resilience 
(Markowitz 1952; Laeven and Levine 2007; Buch et al. 2012; Cetorelli et al. 2014; Cetorelli and Goldberg 2016; Berger et al. 2016).

Our results reconcile these two apparently contradictory hypothesis, showing that bank complexity can be associated both with more and less risk. Operating across many regions, notably in emerging market economies, is more likely to create moral hazard and agency problems, thus leading to more risk. Having a complex business structure and operating across different business types can allow for more diversification and scale benefits, thus leading to lower risk levels.

\section{Data}

Our empirical analysis is based on quarterly bank-level data obtained from supervisory reports, for the period between 2014 and 2018. These reports include data on 17 banking holding companies (BHC). Standalone banks are excluded from the analysis, given that most of the complexity indicators would not have a meaningful interpretation.

The first building block of our analysis are the complexity measures. Bank complexity is in itself a complex concept and we will rely on a broad set of indicators to rank banks according to their complexity (Cetorelli et al. 2014; Goldberg and Meehl 2019). Most of the measures are constructed using end-of-year data on the activities of banking groups. The second pillar is the construction of bank-level risk-taking indicators, also using supervisory data. Finally, to study the relationship between complexity and risk, we need to control for relevant bank characteristics. Below we describe in detail each of the data blocks.

\subsection{Measuring bank complexity}

We consider two broad concepts of bank complexity: geographical complexity and structural complexity.

Geographical complexity describes how affiliate entities are spanned across regions or countries. Arguably, operating across a larger set of geographies adds complexity to the management of the banking groups. That said, this wider reach also promotes diversification. The relationship between geographical complexity and risk can thus be positive or negative.

To measure geographical complexity we start by considering the number of countries in which a banking group operates. On average banks have activities in 5 different countries, but there is significant variation, as some banks operate only in Portugal, while other are present in 16 countries (Table 1). These banks do not hold vastly complex structures in their foreign operations, as the number of foreign affiliates is only slightly larger: banks have, on average, 8.5 affiliates abroad. Not all these foreign operations are related to banking. The average number of foreign affiliates is 4 , which means that when a banking group operates in another country, 
it typically does so only through one bank. The remaining affiliates may also be financial institutions, but they are not deposit-taking institutions.

The cross-border activity of Portuguese banks hinges on two pillars. Part of their operations refers to activity in other European countries, while another important part refers to activity in Africa, notably in former Portuguese colonies. In terms of complexity, these two universes may be quite different. While in Europe most of the regulatory and supervisory framework is common (or very similar), in African emerging economies there are important differences not only in these frameworks, but also on the design and effectiveness of the legal system or on corporate governance (La Porta et al. 2000; Levine et al. 2000; Beck et al. 2006, 2011; Correa and Goldberg 2019). Furthermore, the risks that banks are exposed to might also be different in these two geographies. In order to examine how banks' exposures to emerging markets may shape the relationship between complexity and risk, we add to the set of geographical complexity the number of affiliates each banking group has in Africa. We find that, on average, each banking group has one affiliate in Africa. However, there is a lot of heterogeneity in this variable. Only $40 \%$ of the banking groups actually have operations in Africa through affiliates.

The second concept of complexity that we explore is not related to geography, but rather to business complexity. In this dimension, we consider a set of indicators that capture the structural complexity of a banking group by looking into how the group is organized through affiliates and business types. The simplest indicator that we consider is the number of affiliates of each banking group. This number ranges from 1 to 91 affiliates in each group. The median number of affiliates in each group is 16 .

Another dimension of structural complexity derives from the number of activities carried out within each banking group. Bank holding companies can operate in non-banking financial activities, such as insurance, mutual funds or advisory services, as well as on non-financial activities. Some banking groups in our sample have operations in a broad set of sectors, such as tourism, real estate or health care. One of the indicators we use to capture this complexity is the share of non-financial business types, defined as the percentage of the group's non-financial activities.

On average, only $45 \%$ of the types of business carried out by the banking groups in our sample refer to the financial sector. Once more, there is considerable heterogeneity. Some groups are highly focused on financial activities, with a share of non-financial business types of $33 \%$. Other groups are highly diversified and non-financial activities account for $91 \%$ of their operations.

We also consider the number of business activities within each banking group. On average, each group engages in 3.5 activities, but this number varies from 1 to 11 . Finally, we also compute the Herfindahl-Hirschman Index (HHI) for business types, which equals 0 when a group operates only in one business type. On average, the $\mathrm{HHI}$ stands at 0.66 . 
Taken together, these indicators show that Portuguese banks operate in several geographies and engage in diversified activities, though there is significant dispersion across banks.

When we consider the evolution of complexity indicators during the sample period, we see that most of the indicators showed a downward trend from 2014 to 2018 (Figures 1 and 2). That said, the decrease was concentrated in the first two years of our analysis. This reflects the adjustment of the Portuguese banking sector in the aftermath of the euro area sovereign debt crisis. Regulatory and supervisory changes, such as the implementation of systemic buffers or the creation of the Single Supervisory Mechanism (SSM), might have provided incentives for a decrease in complexity. The only exception to this broad-based decrease in complexity comes from the $\mathrm{HHI}$ for business types, which increased throughout most of the sample period.

To better characterize the heterogeneity within the banking sector, in Table 2 we compare the complexity indicators for the 6 largest banking groups with the smaller banking groups. These 6 largest banking groups are classified as systemically important institutions in Portugal, being subject to the O-SII buffer foreseen in the European regulation. This buffer is calibrated using a systemic risk score that depends on each bank's size, importance for the economy, interconnection, potential contagion, and complexity. The complexity metrics used to calibrate the O-SII buffer are the notional value of OTC derivatives, cross-jurisdictional liabilities and cross-jurisdictional claims. Even though these metrics differ from the ones used in our analysis, we would expect them to be significantly correlated.

The statistics reported in Table 2 confirm this. The 6 largest banks in Portugal operate in more countries, and have more foreign affiliates. Most of them have activities in Africa, while most of the smaller banks do not. They also rank higher in terms of structural complexity: they have more affiliates and operate in more types of business activities.

\subsection{Measuring bank risk}

Risk is part of a bank's business and there are many ways to measure it. Some indicators focus on specific risk dimensions, such as credit risk. Others are more encompassing, but sometimes not focused only on risk. Given the challenges in measuring risk, we consider four different indicators, which we summarize in Table 3.

The first indicator is a measure of financial risk designed to capture the banks' risk of default, by taking into account the volatility of returns and the bank's leverage (In z_score). It is computed as the logarithm of the inverse of the average return on assets in a given period plus the equity to assets ratio of the bank, divided by the standard deviation of the return on assets (in the last eight quarters). The higher the z-score, the higher the risk. According to this indicator, risk increased slightly in 2015, in the aftermath of the bail-in of one of the largest Portuguese banks (Beck et al. 2020). After that year, the z-score for Portuguese 
banks showed a sustained decrease, although with substantial heterogeneity across banks. Nonetheless, this trend in risk reduction seems to have been halted in 2018.

We can also capture risk by using granular information on the banks' exposures. To do that, we consider the logarithm of the average default probability of the loans granted to firms by each bank, using the output of an in-house firm-level credit scoring model (Antunes et al. 2016). The average default probability of firms in the portfolio of the banks between 2014 and 2018 is 7\%. This relatively high number reflects the protracted recovery of the Portuguese economy in the aftermath of the euro area sovereign debt crisis. Further, while the z-score started to decrease only in 2016, the default probability of banks' corporate portfolios decreased markedly already in 2015. Again, there is considerable dispersion in the average default probability in each banks' corporate loan book, reflecting a diversified exposure in terms of risk profiles.

Another way to capture banks' risk-taking is to consider the evolution of non-performing loans (NPL). We consider a flow indicator (New NPL / Assets), which captures the flow of impairments and provisions recorded in each year, as a percentage of total assets. The variation within the sample is substantial. On average, new non-performing loans in each year represent $0.52 \%$ of banks' assets, but this ratio ranges from -1.43 to $2.66 \%$. The flow of non-performing loans has been steadily declining since 2014, reflecting a consistent effort to improve the quality of banks' assets in the aftermath of the financial assistance program to the Portuguese economy (Bonfim et al. 2020).

Finally, a broad way to capture the risks taken by a financial institution is to consider the ratio between risk-weighted assets and total assets (RWA / Assets). A bank with high risk-weighted assets to total assets has high risk weights attached to its assets. While this could mean that the bank has more prudent risk management policies, the fact that only three banks in Portugal use internal credit risk models to estimate regulatory capital requirements suggests instead that higher risk weights reflect higher risk-taking levels. The sample average ratio is 0.61 , but it ranges from 0.4 to 0.94 , confirming that there is substantial variety in risk profiles in the Portuguese banking sector. This indicator also decreased towards less risk during the period analyzed.

If we jointly consider the evolution of complexity and risk indicators, we observe that both have been declining in the last years, for most of the indicators considered. Still, these aggregate time trends might hide important cross-sectional variation. When we compute pairwise correlations between the complexity and risk indicators, the positive relationship is generally confirmed.

\subsection{Bank characteristics}

The apparent positive unconditional correlation between risk and complexity indicators might be hiding the role of other bank characteristics that also influence bank risk and bank complexity. It is thus crucial to control for potentially relevant bank characteristics in a multivariate setting. 
In Table 4 we report the summary statistics for a set of bank characteristics. Bank size, captured by the logarithm of total assets (In Assets), is often associated with risk-taking, as larger banks might be perceived as too-big-to-fail (DemirgüçKunt and Huizinga 2013). The implicit belief of a bailout might lead to excessive risk (Gropp et al. 2011).

We also control for the ratio between loans and assets. This indicator captures banks' specialization in lending, thus reflecting the banks' business model. Banks with a larger fraction of total assets linked to loans to customers have a more traditional intermediation profile, which is often associated with less risk. There is substantial variation in our sample, with a minimum of $1.8 \%$ and a maximum of $96 \%$, showing that there are different business models. On average, slightly more than half of the banks' total assets refer to bank loans.

Bank profitability might also be a relevant control variable. In the sample, banks' return on assets (ROA) is on average $0.76 \%$, showing a gradual improvement during the sample period. Many banks still recorded losses during part of the sample period, mainly due to the recognition of impairments in their loan books in the aftermath of the euro area sovereign debt crisis.

We also control for bank efficiency, captured by the cost-to-income ratio. On average this ratio stood at 60.5, showing a persistent improvement since 2016 . This improvement reflects both the growth in income mentioned above and the adoption of cost-cutting measures, such as massive branch closures (Bonfim et al. 2019).

Finally, we also control for the effects of bank capital on risk. Better capitalized banks are expected to take less risks, as shareholders have more skin in the game (Berger and Bouwman 2013; Peek and Rosengren 2005; Blattner et al. 2019). Banks' Tier 1 ratio was on average $16.1 \%$ and showed a significant improvement during the period analyzed.

\section{Complexity and risk-taking}

\subsection{Empirical strategy}

Our main goal is to understand whether complexity is associated with more or less bank risk. On the one hand, more complex banks are less transparent and so may be more prone to take risk. On the other hand, more complex banks are also more diversified, which may be linked to less risk.

To explore the direct link between complexity and risk-taking of Portuguese banks, we estimate the following model:

$$
\text { Risk }_{i t}=\beta_{0}+\beta_{1} \text { Complexity }_{i, t-1}+\delta X_{i, t-1}+\gamma_{t}+\varepsilon_{i t}
$$

where $i$ denotes an individual bank and $t$ denotes time. The term Risk will capture banks' risk-taking and Complexity is the set of bank complexity indicators, which enter the model one at a time. In these regressions we will control for bank-specific 
time-varying characteristics captured by the vector $X_{i, t-1}$ and time fixed effects $\gamma_{t}{ }^{1}$ The independent variables are lagged by one period. The term $\varepsilon_{i t}$ is an error term with the conventional statistical properties. This specification allows us to contribute to the debate on the link between risk and complexity. As discussed above, the evidence available in the literature is mixed regarding the expected sign of $\beta_{1}$. Complexity may be a synonym for diversification, thus implying less risk, or for opacity, having an opposite effect. With this specification we can better understand the (non-causal) relationship between these two dimensions.

\subsection{Main results}

3.2.1. Geographical complexity and risk. In Table 5 we report the results for the estimation of Equation (1) for the relationship between geographical complexity and the most encompassing risk indicator in our analysis, the logarithm of banks' $z$-scores. The z-score is the inverse of the average return on assets in a given period plus the equity to assets ratio of the bank, divided by the standard deviation of the return on assets in the last 8 quarters. This means that a higher z-score is associated with more risk through the combination of more leverage and more volatility of returns (Boyd et al. 1993). Both dimensions are by themselves important signs of bank fragility. Their combination renders banks especially vulnerable, as a high leveraged bank coping with volatile returns will find it much harder to withstand negative shocks.

We estimate the relationship between banks' z-score and each one of the five geographical complexity indicators: Number of countries, Number of foreign affiliates, Number of foreign bank affiliates, Number of affiliates in Africa, Dummy variable for affiliates in Africa. None of the first three dimensions shows a statistically significant relationship with banks' z-scores. Banking groups operating in more countries, with more foreign bank and non-bank affiliates do not have significantly different $z$-scores from banks that have less geographical complexity.

However, we find a significant positive relationship between the indicators that capture geographical complexity through exposure to emerging market economies (namely to Africa). Banks that have more affiliates in Africa show higher z-scores. The relationship is stronger when we consider only the effect of having or not exposure to Africa through local affiliates.

The higher risk associated with operations in Africa captured by the z-score might be related to the higher volatility of returns in these economies. The most significant part of the exposure refers to Angola, an oil-exporting economy. This means that banks' operations in this country are affected by fluctuations in oil prices and exchange rates, leading to larger volatility in their returns (IMF 2016).

1. We do not consider bank fixed effects in the estimated models because of the short time span of the dataset. 
In Table 6, we report the results of geographical complexity on the average default probability in banks' corporate loan portfolio (In PD). This indicator captures a very different dimension of bank's risk. While the z-score considers the capital structure and volatility of returns, this indicator zooms in on one of the main sources of bank losses: corporate loans. Using an in-house credit scoring model with granular loan and firm information (Antunes et al. 2016), we compute the average default probability in each bank's corporate loan book.

The results are very different when we use this indicator. Now we find that the first three geographical complexity measures (Number of countries, Number of foreign affiliates, Number of foreign bank affiliates) are positively related with the risk banks take in their corporate loan book. It is important to note that the default probabilities are computed only for domestic firms. This means that banks that have stronger activity abroad, both through banks and through other activities, are exposed to more corporate risk domestically. One possible explanation for this result might be related to higher risk tolerance for the banks that choose to expand abroad. That said, the results do not point to any link between activities in Africa and risk in banks' domestic corporate loan book.

The results for the third risk indicator, new NPLs over total assets, are broadly consistent with those obtained with the average default probabilities (Table 7 ). Banks that operate in more countries, both through banking and non-banking activities, show higher increases in NPLs. Once more, this relationship does not hold for activities in Africa.

The consistency between the results obtained with average default probabilities and new NPLs is not unexpected. Most of the loan losses recorded in the Portuguese banking sector during the euro area sovereign debt crisis were in the corporate loan book (Marques et al. 2020). Banks with a portfolio of riskier borrowers are thus expected to also be those with more NPLs.

Finally, we examine the relationship between geographical complexity and the risk-weighted assets ratio (Table 8 ). This indicator offers an encompassing view of the riskiness of the entire portfolio of bank assets. The higher the risk weights assigned to banks' assets, the higher the risk in the balance sheet. The results show that there is also a positive relationships between geographical complexity and this risk indicator. However, this relationships occurs only through the number of countries and the number of foreign affiliates. The number of foreign bank affiliates does not seem have a significant relationship with risk as measured by the risk-weighted ratio, suggesting that the link exists mainly through non-bank activities abroad which might, in some cases, have higher risk weights attached. Finally, operations in Africa do not have a statistically significant relationship with the risk weighted assets ratio.

In sum, we find a significant positive relationship between geographical complexity and banks' risk. This relationship has two main dimensions. First, banks more exposed to Africa show higher risk as captured by z-scores. This possibly reflects the volatility in returns generated by these exposures. Second, the number of countries in which a bank operates, including both bank and non-bank activities, 
is positively related with the riskiness of banks' assets, captured by corporate default probabilities, non-performing loans and risk-weights.

3.2.2. Structural complexity and risk. Geographical and structural complexity refer to different dimensions of complexity. While some banks have complex internal structures and also operate in a wide set of regions, other banks, often smaller, have very simple structures and operate dominantly in the domestic market. That said, most banks are somewhere in the middle of these extremes, ranking high in one of the dimensions but not in the other. For this reason, we repeat the analysis of the previous sub-section, but now looking into four indicators of structural complexity: number of affiliates, share of non-financial business types, number of business types, and $\mathrm{HHI}$ for business types.

In Table 9 we report the results for the estimation of Equation (1) using structural complexity indicators for the first bank risk indicator, the z-score. We find a negative significant relationship between the number of affiliates a bank has and the z-score. Banks with more complex internal structures reflected in a larger number of affiliates show lower levels of risk. This result contrasts with the positive relationship between risk and geographical complexity. One possible explanation for this result might be that banks with more affiliates are more diversified, which allows them to mitigate the volatility of their income stream (Baele et al. 2007; Goddard et al. 2008).

The negative relationship between structural complexity and risk, captured by the $z$-score, works through the number of affiliates, but not through the other three indicators that capture complexity through the composition of activities carried out by these affiliates. Having a larger share of non-financial activities, a larger number of business types or a higher $\mathrm{HHI}$ in business types is not positively nor negatively related with our broader measure of risk, the z-score.

In Tables 10, 11, and 12, we report the relationship of the four structural complexity indicators with the remaining three bank risk indicators: the average default probability of the corporate loan book, new NPLs over total assets and the risk-weighted assets ratio. We cannot find any statistically significant relationship between structural complexity and banks' risk-taking in any of these estimations.

While for geographical complexity we could document a consistently positive relationship between complexity and risk, with structural complexity we find a negative relationship between the number of affiliates and risk measured by the zscore, but not for any other complexity or risk indicator. This suggests that the link between structural complexity and risk is weaker than for geographical complexity.

\subsection{Complexity, risk and regulation: an instrumental variables approach}

The results presented so far do not allow us to establish a causal relationship between complexity and risk. The link between these two dimensions may be endogenous for a number of different reasons, including reverse causality and omitted variables. For instance, banker managers' (time-varying) risk tolerance 
may shape decisions both on the level of geographical and structural complexity and on the riskiness of assets held.

To help us in getting closer to a causal analysis, we explore one recent change in bank regulation: the announcement of the Other Systemically Important Institutions capital buffer (O-SII buffer).

The systemic risk buffer was one of the solutions put forth by the Basel Committee in the aftermath of the global financial crisis to mitigate banks' contribution to systemic risk due to their size and complexity. Global banks that are considered systemic have to hold additional capital buffers, thus contributing to a better alignment of incentives. At the European level, the Capital Requirements Directive allows national macroprudential authorities to impose capital buffers on banks that are systemically relevant in each jurisdiction (Budrys et al. 2018). Banco de Portugal adopted this framework in 2015, initially front-loading some of the implementation foreseen in international regulation. Six of the largest banking groups have been classified as O-SII, based on a set of criteria related to each bank's size, its importance for the economy, its interconnection and potential connection and, finally, its complexity. ${ }^{2}$ These six banks can be subject to additional capital requirements, ranging from 0 to $2 \%$ of the total risk exposure amount. ${ }^{3}$ If this capital buffer is a binding constraint for the banks' desired or optimal capital level, banks may choose to react in three different ways: i) they may increase their Core Tier 1 capital (CET1) to meet the new requirements; ii) they may reduce riskweighted assets (RWA); or iii) they may decrease their contribution to systemic risk, thus reducing their O-SII buffer in the future. While the first two adjustment mechanisms are similar to those seen after the implementation of any capital requirement, the last one is specific to this buffer. Indeed, the third adjustment mechanism is deeply intertwined with complexity, as this is one of the ingredients in the calibration of the O-SII score. According to the guidelines of the European Banking Authority (EBA), the score is computed using four categories of indicators: size, importance, complexity and interconnectedness. Each one of these categories has a weight of $25 \%$ on the computation of the score, which can then be finetuned using supervisory judgment. Complexity is captured by the (notional) value of OTC derivatives, cross-jurisdictional claims and cross-jurisdictional liabilities. Though these metrics differ from the complexity indicators used in this paper, we expect them to be significantly correlated.

Given that these buffers create an exogenous incentive for banks to decrease their complexity levels, we explore this regulatory shock in an instrumental variables setting. We examine how bank complexity affects banks' risk taking behaviors by exploring an exogenous shock coming from a regulatory tool that targets the complexity of banks, thus exploring the idea that regulation might have an

2. Methodological details on the calibration of O-SII buffers can be found in https://www.bportugal.pt/sites/default/files/anexos/doc_osii_en_0.pdf.

3. In Table 2 we report the complexity indicators for banks that are classified as O-SIls and for the other banks in the sample. 
important role in shaping the link between complexity and risk in banking (Laeven and Levine 2009; DeYoung et al. 2013; Brandao-Marques et al. 2018).

We re-estimate Equation 1 in a two-stage least square framework, where the OSII buffer is an instrumental variable for banks' complexity. The first stage equation can be written as follows:

$$
\text { Complexity }_{i t}=\beta_{0}+\beta_{1} O-S I I_{i, t-1}+\delta X_{i, t-1}+\gamma_{t}+\varepsilon_{i t}
$$

This empirical specification allows us to explore the intensity of the treatment, given that the buffer is calibrated individually for each banking group, depending on its contribution to systemic risk. As such, this empirical strategy allows to explore the time-series and cross-sectional variation in the calibration of systemic risk buffers for Portuguese banks.

3.3.1. Results. In Tables 13 to 20 we repeat the estimations reported in Tables 5 to 12 using the instrumental variables approach. Part of the results are consistent, but there are also some noteworthy differences.

In Table 13 we report the results of the effects of geographical complexity on banks' z-score. When we use an instrumental variables approach to mitigate endogeneity concerns, the results still support a positive relationship between geographical complexity and bank's risk captured by the z-score. However, while in the OLS approach the results were statistically significant only for the exposures to Africa, with this estimation strategy we continue to obtain a positive relationship between presence in Africa and risk (though only for the number of affiliates in Africa) but we also find a (marginally) statistically significant relationship for the number of countries in which a bank operates, as well as for the number of foreign affiliates. The results for the first-stage of the estimation confirm that the O-SII buffer is a valid instrument, except for the binary variable that refers to exposures in Africa.

When we consider the effects of geographical complexity on the average corporate default probability of banks, the statistically significant positive effects we obtained in the OLS specification are no longer valid (Table 14). This positive relationship was possibly affected by omitted variables which simultaneously influence banks' complexity and risk, such as bank manager's risk preferences.

In contrast, the effects of geographical complexity on new non-performing loans become stronger with the instrumental variables approach (Table 15). Banks that operate in more countries, both through bank and non-bank affiliates, have larger NPL flows (the coefficients are more precisely estimated). Further, the effect of the number of affiliates in Africa becomes statistically significant in the instrumental variables approach.

Finally, the effect of geographical complexity on banks' risk as measured by the risk weighted ratio is not significant in the instrumental variables estimation (Table 16), suggesting that this result was possibly affected by endogeneity problems.

In sum, when we explore the role of the announcement of the O-SII buffer as an instrument that exogenously affects complexity, the results do not remain entirely 
unchanged. That said, the most important conclusion of our analysis remains valid. There is a positive relationship between geographical complexity and banks' risk.

The next step is to estimate the instrumental variables approach for the effect of business complexity on the four risk variables: z-score (Table 17), average corporate default probability (Table 18), new NPLs (Table 19), and the risk weighted asset ratio (Table 20). In the OLS estimation, the relationship between structural complexity and risk was very weak. We could only find a negative relationship between the number of affiliates and risk measured by the z-score. The results are broadly the same with the instrumental variables approach. There is a marginally statistically significant coefficient on the effects of the share of non-financial business types on banks' z-score. Banks with a larger share of nonfinancial activities have more risk. None of the other complexity-risk combinations yields statistically significant results. Further, the results for the first step are also generally not-statistically significant. Even though the announcement of the O-SII buffer was associated with changes in geographical complexity, it did not lead to changes in structural complexity.

3.3.2. Additional results. In the results presented in Tables 13 to 20 , the instrumental variable used in the first step refers to the announced O-SII buffer for each institution, which can vary from 0 to $2 \%$. In unreported estimations, we also considered as an instrument a binary version of this variable, taking the value one for all the banking groups classified as O-SII from 2015 onwards.

The results confirm a positive relationship between geographical complexity and bank risk, but only in one case: the effect of having or not activities in Africa on banks' z-score. The weaker results for the binary version of the instrumental variable are essentially linked to its weaker performance in the first stage of the estimations.

However, for structural complexity the results are stronger with this binary instrument, which performs better in the first stage estimation of complexity. Although the majority of complexity-risk links remains not statistically significant, there is a significant negative effect of the share of non-financial business types and of the number of business types on banks' z-score. There is also a negative effect of the share of non-financial business types on new NPLs.

The period analyzed in the paper corresponds to the first years of the Single Supervisory Mechanism (SSM). In 2014, the ECB became responsible for the direct supervision of "significant institutions" in the euro area. The set of Portuguese institutions that became directly supervised by the ECB in 2014 greatly overlaps, albeit not entirely, with the set of institutions subject to O-SII buffers. When we consider as an instrumental variable a dummy that captures whether or not a banking group is supervised directly by the ECB, the results are generally consistent with those previously obtained, though more imprecisely estimated. 


\section{Concluding remarks}

The existing literature on the relationship between bank complexity and risk offers ambiguous predictions. On the one hand, bank complexity can be linked to moral hazard and agency problems. This means that more complex banks are expected to have higher levels of risk. On the other hand, being more complex might allow banks to benefit from diversification and from scale economies. This implies that more complex banks can have lower levels of risk.

In this paper, we examine a set of complexity and risk indicators to shed more light on these conflicting predictions. We discuss two types of complexity: geographical and structural. The link between these two concepts of complexity and risk has opposite signs. We find a positive relationship between geographical complexity and bank risk. Banks that operate in more countries, both through banks and non-banks, have higher risk in their balance sheets. Their credit portfolios have, on average, higher default probabilities, they have more new non-performing loans, and they have higher risk-weights per unit of exposure. In contrast, we find a (weak) negative relationship between structural complexity and bank risk. Banks that have more affiliates show higher levels of risk as captured by the z-score. That said, for most structural complexity indicators, we do not find a statistical significant relationship with risk.

Geographical complexity may be captured by the number of countries and affiliates that a banking group has abroad, but considering what type of countries this exposure refers to might also be relevant. We explore the heterogeneous exposure of Portuguese banks to Africa to understand how is complexity, as captured through exposure to an emerging market economy, related to risk. We find that banks that operate in Africa indeed have higher levels of risk, as captured by the $z$-score. This reflects the larger volatility of returns arising from these exposures. However, exposure to Africa is not related to other risk indicators that capture the overall risk in banks' balance sheets.

Taken together, our results validate two apparently contradictory hypotheses. Bank complexity can be associated with both more and less risk. Geographical complexity is more likely to create moral hazard and agency problems, thus leading to more risk, notably when banks operate in many geographies and in volatile emerging markets. In turn, structural complexity can allow for more diversification and scale benefits, thus leading to lower risk levels. 


\section{References}

Acharya, Viral V, Deniz Anginer, and A Joseph Warburton (2016). "The end of market discipline? Investor expectations of implicit government guarantees."

Antunes, António, Homero Goncalves, and Pedro Prego (2016). "Firm default probabilities revisited." Economic Bulletin and Financial Stability Report Articles.

Baele, Lieven, Olivier De Jonghe, and Rudi Vander Vennet (2007). "Does the stock market value bank diversification?" Journal of Banking \& Finance, 31(7), 1999-2023.

Beck, Thorsten (2015). "Cross-border banking and financial deepening: The African experience." Journal of African Economies, 24(1), 32-45.

Beck, Thorsten and Robert Cull (2013). Banking in Africa. The World Bank.

Beck, Thorsten, Samuel Da-Rocha-Lopes, and André Silva (2017). "Sharing the pain? Credit supply and real effects of bank bail-ins." Mimeo.

Beck, Thorsten, Samuel Da-Rocha-Lopes, and André F Silva (2020). "Sharing the pain? Credit supply and real effects of bank bail-ins." Review of Financial Studies.

Beck, Thorsten, Aslı Demirgüç-Kunt, and Ross Levine (2006). "Bank supervision and corruption in lending." Journal of monetary Economics, 53(8), 2131-2163.

Beck, Thorsten, Samuel Munzele Maimbo, Issa Faye, and Thouraya Triki (2011). Financing Africa: Through the crisis and beyond. The World Bank.

Berger, Allen N and Christa HS Bouwman (2013). "How does capital affect bank performance during financial crises?" Journal of Financial Economics, 109(1), 146-176.

Berger, Allen N, Sadok El Ghoul, Omrane Guedhami, and Raluca A Roman (2016). "Internationalization and bank risk." Management Science, 63(7), 2283-2301.

Blattner, Laura, Luísa Farinha, and Francisca Rebelo (2019). "When losses turn into loans: the cost of undercapitalized banks."

Bonfim, Diana, Geraldo Cerqueiro, Hans Degryse, and Steven Ongena (2020). "On-site inspecting zombie lending." CEPR Discussion Paper No. DP14754.

Bonfim, Diana, Gil Nogueira, and Steven Ongena (2019). "'Sorry, We're Closed': Bank Branch Closures and Corporate Credit Conditions." Mimeo.

Boyd, John H, Stanley L Graham, and R Shawn Hewitt (1993). "Bank holding company mergers with nonbank financial firms: Effects on the risk of failure." Journal of banking \& finance, 17(1), 43-63.

Brandao-Marques, Luis, Ricardo Correa, and Horacio Sapriza (2018). "Government support, regulation, and risk taking in the banking sector." Journal of Banking \& Finance.

Buch, Claudia M, Cathérine T Koch, and Michael Koetter (2012). "Do banks benefit from internationalization? Revisiting the market power-risk nexus." Review of Finance, 17(4), 1401-1435.

Budrys, Zymantas, Giuseppe Cappelletti, Áurea Pontes Marques, and Paulo Varraso (2018). 'Impact of higher capital buffers on banks' lending: Evidence from the euro area experiments." Mimeo. 
Carmassi, Jacopo and Richard Herring (2016). "The corporate complexity of global systemically important banks." Journal of Financial Services Research, 49(2-3), 175-201.

Cetorelli, Nicola and Linda Goldberg (2016). "Organizational complexity and balance sheet management in global banks." NBER Working Paper No. 22169.

Cetorelli, Nicola, James McAndrews, and James Traina (2014). "Evolution in bank complexity." FRBNY Economic Policy Review, pp. 85-106.

Cetorelli, Nicola and James Traina (2018). "Resolving "Too Big to Fail"." FRBNY Staff Report No. 859.

Chernobai, Anna, Ali Ozdagli, and Jianlin Wang (2020). "Business complexity and risk management: Evidence from operational risk events in US bank holding companies." Journal of Monetary Economics.

Correa, Ricardo and Linda S Goldberg (2019). "Bank Complexity, Governance, and Risk." Mimeo.

Dam, Lammertjan and Michael Koetter (2012). "Bank bailouts and moral hazard: Evidence from Germany." The Review of Financial Studies, 25(8), 2343-2380.

Demirgüç-Kunt, Asli and Harry Huizinga (2013). "Are banks too big to fail or too big to save? International evidence from equity prices and CDS spreads." Journal of Banking \& Finance, 37(3), 875-894.

Demirgüç-Kunt, Asli and Leora Klapper (2012). Financial inclusion in Africa: an overview. The World Bank.

DeYoung, Robert, Emma Y Peng, and Meng Yan (2013). "Executive compensation and business policy choices at US commercial banks." Journal of Financial and Quantitative Analysis, 48(1), 165-196.

Duchin, Ran and Denis Sosyura (2014). "Safer ratios, riskier portfolios: Banks' response to government aid." Journal of Financial Economics, 113(1), 1-28.

Farhi, Emmanuel and Jean Tirole (2012). "Collective moral hazard, maturity mismatch, and systemic bailouts." American Economic Review, 102(1), 60-93.

Goddard, John, Donal McKillop, and John OS Wilson (2008). "The diversification and financial performance of US credit unions." Journal of Banking \& Finance, 32(9), 1836-1849.

Goldberg, Linda S and April Meehl (2019). "Complexity in large US banks." FRB of New York Staff Report, (880).

Gropp, Reint, Hendrik Hakenes, and Isabel Schnabel (2011). "Competition, riskshifting, and public bail-out policies." The Review of Financial Studies, 24(6), 2084-2120.

IMF (2016). "Portugal: Third Post-Program Monitoring."

La Porta, Rafael, Florencio Lopez-de Silanes, Andrei Shleifer, and Robert Vishny (2000). "Investor protection and corporate governance." Journal of financial economics, 58(1-2), 3-27.

Laeven, Luc and Ross Levine (2007). "Is there a diversification discount in financial conglomerates?" Journal of Financial Economics, 85(2), 331-367.

Laeven, Luc and Ross Levine (2009). "Bank governance, regulation and risk taking." Journal of financial economics, 93(2), 259-275. 
Levine, Ross, Norman Loayza, and Thorsten Beck (2000). "Financial intermediation and growth: Causality and causes." Journal of monetary Economics, 46(1), 3177.

Markowitz, Harry (1952). "Portfolio selection." The journal of finance, 7(1), 77-91. Marques, Carla, Ricardo Martinho, and Rui Silva (2020). "Non-performing loans and bank lending: Evidence for Portugal." Banco de Portugal Economic Studies, $\mathrm{VI}(1)$.

Morgan, Donald P (2002). "Rating banks: Risk and uncertainty in an opaque industry." American Economic Review, 92(4), 874-888.

Peek, Joe and Eric S Rosengren (2005). "Unnatural selection: Perverse incentives and the misallocation of credit in Japan." American Economic Review, 95(4), 1144-1166. 


\section{Tables and Figures}

\begin{tabular}{lcccccccc}
\hline & Count & Mean & St. dev. & Min. & Q1 & Q2 & Q3 & Max. \\
\hline Geographical complexity & & & & & & & & \\
Number of countries & 64 & 5.27 & 4.11 & 1 & 1 & 4 & 8.5 & 16 \\
Number of foreign affiliates & 64 & 8.50 & 9.21 & 0 & 0 & 6 & 13 & 32 \\
Number of foreign bank affiliates & 64 & 4.03 & 4.08 & 0 & 0 & 3 & 6 & 17 \\
Number of affiliates in Africa & 64 & 1.09 & 1.80 & 0 & 0 & 0 & 2 & 8 \\
Dummy variable for affiliates in Africa & 64 & 0.42 & 0.50 & 0 & 0 & 0 & 1 & 1 \\
\hline Structural complexity & & & & & & & & \\
Number of affiliates & 64 & 26.16 & 26.92 & 1 & 4.5 & 16 & 43.5 & 91 \\
Share of non-financial business types & 45 & 0.55 & 0.15 & 0.33 & 0.50 & 0.50 & 0.60 & 0.91 \\
Number of business types & 64 & 3.53 & 2.32 & 1 & 2 & 3 & 4 & 11 \\
HHI business types & 56 & 0.66 & 0.26 & 0.14 & 0.44 & 0.74 & 0.88 & 1.00 \\
\hline
\end{tabular}

Table 1. Summary statistics on complexity indicators

Notes: The sample period goes from 2014 to 2018. Count refers to the number of observations and Q1, Q2, and Q3 refer to the first, second, and third quartiles of the sample distribution of each complexity indicator, respectively. The number of countries counts the countries in which each banking group operates. The number of foreign affiliates considers all branches and subsidiaries abroad, while the number of foreign bank affiliates considers only foreign branches and subsidiaries registered as banks. The number of affiliates (in Africa) counts all affiliates (in Africa). The share of non-financial business types captures the percentage of the group's non-financial activities. The $\mathrm{HHI}$ for business types refers to the Herfindahl-Hirschman Index for business types and equals 0 when a group only operates in one business type.

\begin{tabular}{lcccc}
\hline & $\begin{array}{c}\text { Largest } 6 \text { banks } \\
(\text { mean }) \\
(1)\end{array}$ & $\begin{array}{c}\text { Other banks } \\
(\text { mean }) \\
(2)\end{array}$ & $\begin{array}{c}\text { Difference } \\
(3)\end{array}$ & $\begin{array}{c}t \text {-statistic } \\
(4)\end{array}$ \\
\hline Geographical complexity & & & & \\
Number of countries & 7.93 & 2.91 & $-5.02^{* * *}$ & -6.12 \\
Number of foreign affiliates & 13.73 & 3.88 & $-9.85 * * *$ & -5.03 \\
Number of foreign bank affiliates & 6.57 & 1.79 & $-4.77^{* * *}$ & -5.72 \\
Number of affiliates in Africa & 2.17 & 0.15 & $-2.02^{* * *}$ & -5.40 \\
Dummy variable for affiliates in Africa & 0.73 & 0.15 & $-0.59^{* * *}$ & -5.79 \\
\hline Structural complexity & & & & \\
Number of affiliates & 39.53 & 14.35 & $25.18^{* * *}$ & -4.20 \\
Share of non-financial business types & 0.58 & 0.50 & -0.08 & -1.83 \\
Number of business types & 4.43 & 2.74 & $-1.70^{* *}$ & -3.12 \\
HHI business types & 0.58 & 0.74 & $0.16^{*}$ & 2.36 \\
\hline
\end{tabular}

Table 2. Summary statistics on complexity indicators: largest 6 banks vs. other institutions

Notes: The sample period goes from 2014 to 2018. The largest 6 banks (G6) refer to the sub-sample of systemically important institutions. Column (1) reports means for this group of banks and column (2) reports the means for the other banks. Column (3) reports the differences between these two sub-samples and column (4) reports the t-statistic under the null hypothesis of no difference of means between the two sub-samples. The number of countries counts the countries in which each banking group operates. The number of foreign affiliates considers all branches and subsidiaries abroad, while the number of foreign bank affiliates considers only foreign branches and subsidiaries registered as banks. The number of affiliates (in Africa) counts all affiliates (in Africa). The share of non-financial business types captures the percentage of the group's non-financial activities. The $\mathrm{HHI}$ for business types refers to the Herfindahl-Hirschman Index for business types and equals 0 when a group only operates in one business type. ${ }^{* * *}, * *$, and $*$ stand for statistical significance at $1 \%, 5 \%$, and $10 \%$, respectively. 


\begin{tabular}{lcccccccc}
\hline & Count & Mean & St. dev. & Min. & Q1 & Q2 & Q3 & Max. \\
\hline In z-score & 55 & -2.74 & 0.85 & -4.7 & -3.36 & -2.86 & -2.15 & -0.51 \\
In PD & 64 & -2.73 & 0.44 & -3.41 & -3 & -2.78 & -2.5 & -0.46 \\
New NPL / Assets & 64 & 0.52 & 0.75 & -1.43 & 0.05 & 0.31 & 0.91 & 2.66 \\
RWA / Assets & 60 & 0.61 & 0.14 & 0.4 & 0.51 & 0.6 & 0.67 & 0.94 \\
\hline
\end{tabular}

Table 3. Summary statistics on risk-taking indicators

Notes: The sample period goes from 2014 to 2018. Count refers to the number of observations and Q1, Q2, and Q3 refer to the first, second, and third quartiles of the risk measures distribution, respectively. The In z-score is computed as the logarithm of the inverse of the average return on assets in a given period plus the equity to assets ratio of the bank, divided by the standard deviation of the return on assets in the last 8 quarters. Ln PD is computed as the logarithm of the average default probability of loans granted to firms by each bank, using the output of a firm-level credit scoring model (Antunes et al., 2016). New NPL / Assets is the flow of non-performing loans over total assets; and RWA / Assets is the ratio between risk-weighted assets and total assets.

\begin{tabular}{lcccccccc}
\hline & Count & Mean & St. dev. & Min. & Q1 & Q2 & Q3 & Max. \\
\hline In Assets & 64 & 9.07 & 1.89 & 5.23 & 7.49 & 9.65 & 10.77 & 11.52 \\
Loans / assets & 64 & 50.60 & 25.53 & 1.77 & 32.25 & 58.91 & 65.39 & 95.50 \\
ROA & 64 & 0.76 & 1.86 & -4.75 & -0.15 & 0.65 & 1.76 & 7.03 \\
Cost-to-income & 64 & 60.48 & 26.75 & 21.13 & 43.21 & 55.56 & 69.30 & 165.25 \\
Tier 1 ratio & 54 & 16.07 & 11.02 & 0.01 & 10.87 & 13.57 & 20.27 & 60.67 \\
\hline
\end{tabular}

Table 4. Summary statistics on bank characteristics

Notes: The sample period goes from 2014 to 2018. Count refers to the number of observations and Q1, Q2, and Q3 refer to the first, second, and third quartiles of the risk measures distribution, respectively. ROA refers to return on assets. 


\begin{tabular}{lccccc}
\hline & \multicolumn{5}{c}{ Geographical complexity indicator } \\
\cline { 2 - 6 } & $\begin{array}{c}\text { Number of } \\
\text { countries } \\
(1)\end{array}$ & $\begin{array}{c}\text { Number of foreign } \\
\text { foreign affiliates } \\
(2)\end{array}$ & $\begin{array}{c}\text { Number of foreign } \\
\text { bank affiliates } \\
(3)\end{array}$ & $\begin{array}{c}\text { Number of } \\
\text { affiliates in Africa } \\
(4)\end{array}$ & $\begin{array}{c}\text { Dummy variable } \\
\text { for affiliates in Africa } \\
(5)\end{array}$ \\
\hline Geographical complexity & 0.0082 & -0.0046 & -0.0145 & $0.1652^{*}$ & $1.1136^{* * *}$ \\
& $(0.0721)$ & $(0.0407)$ & $(0.0628)$ & $(0.0888)$ & $(0.1793)$ \\
In Assets & 0.3055 & $0.3438^{*}$ & $0.3606^{*}$ & 0.1630 & 0.0394 \\
& $(0.1883)$ & $(0.1872)$ & $(0.1697)$ & $(0.1417)$ & $(0.0816)$ \\
Loans / assets & 0.0052 & 0.0043 & 0.0033 & 0.0070 & 0.0027 \\
ROA & $(0.0054)$ & $(0.0063)$ & $(0.0057)$ & $(0.0061)$ & $(0.0036)$ \\
Cost-to-income & 0.1181 & 0.1087 & 0.1153 & 0.1764 & 0.1254 \\
Tier 1 ratio & $(0.1878)$ & $(0.1884)$ & $(0.1649)$ & $(0.1559)$ & $(0.0957)$ \\
& $0.0152^{*}$ & 0.0143 & 0.0143 & $0.0143^{*}$ & $0.0127^{*}$ \\
\hline$N$ & $(0.0078)$ & $(0.0100)$ & $(0.0081)$ & $(0.0072)$ & $(0.0068)$ \\
adj. $R^{2}$ & $0.0511^{*}$ & $0.0519^{*}$ & $0.0489^{* *}$ & $0.0384^{*}$ & 0.0073 \\
& $(0.0241)$ & $(0.0269)$ & $(0.0168)$ & $(0.0193)$ & $(0.0084)$ \\
\hline
\end{tabular}

Table 5. Geographical complexity and risk: z-score

The table reports the estimation of Equation 1. The dependent variable is the logarithm of the z-score calculated over eight quarters (In Z-score). The In z-score is computed as the logarithm of the inverse of the average return on assets in a given period plus the equity to assets ratio of the bank, divided by the standard deviation of the return on assets in the last 8 quarters. Columns (1) to (5) correspond to the different measures of the independent variable on geographical complexity (Number of countries, Number of foreign affiliates, Number of foreign bank affiliates, Number of affiliates in Africa, Dummy variable for affiliates in Africa). The number of countries counts the countries in which each banking group operates. The number of foreign affiliates considers all branches and subsidiaries abroad, while the number of foreign bank affiliates considers only foreign branches and subsidiaries registered as banks. The number of affiliates (in Africa) counts all affiliates (in Africa). All the independent variables are lagged by one quarter. The sample period goes from 2014 to 2018. All specifications include time fixed effects. Ordinary Least Squares estimates with robust standard errors clustered at the bank level in parentheses. $* * *, * *$, and ${ }^{*}$ stand for statistical significance at $1 \%, 5 \%$, and $10 \%$, respectively. 


\begin{tabular}{|c|c|c|c|c|c|}
\hline & \multicolumn{5}{|c|}{ Geographical complexity indicator } \\
\hline & $\begin{array}{l}\text { Number of } \\
\text { countries } \\
\text { (1) }\end{array}$ & $\begin{array}{l}\text { Number of foreign } \\
\text { foreign affiliates } \\
\text { (2) }\end{array}$ & $\begin{array}{c}\text { Number of foreign } \\
\text { bank affiliates } \\
\text { (3) }\end{array}$ & $\begin{array}{c}\text { Number of } \\
\text { affiliates in Africa } \\
\text { (4) }\end{array}$ & $\begin{array}{l}\text { Dummy variable } \\
\text { for affiliates in Africa } \\
\text { (5) }\end{array}$ \\
\hline Geographical complexity & $\begin{array}{c}0.0546^{* *} \\
(0.0184)\end{array}$ & $\begin{array}{l}0.0220^{* *} \\
(0.0081)\end{array}$ & $\begin{array}{c}0.0293^{* *} \\
(0.0102)\end{array}$ & $\begin{array}{c}0.0385 \\
(0.0262)\end{array}$ & $\begin{array}{c}0.0058 \\
(0.1609)\end{array}$ \\
\hline In Assets & $\begin{array}{c}-0.1114^{* *} \\
(0.0462)\end{array}$ & $\begin{array}{l}-0.0896 \\
(0.0511)\end{array}$ & $\begin{array}{l}-0.0814 \\
(0.0470)\end{array}$ & $\begin{array}{l}-0.0631 \\
(0.0560)\end{array}$ & $\begin{array}{l}-0.0407 \\
(0.0598)\end{array}$ \\
\hline Loans / assets & $\begin{array}{l}-0.0096^{*} \\
(0.0051)\end{array}$ & $\begin{array}{l}-0.0102 \\
(0.0061)\end{array}$ & $\begin{array}{l}-0.0098 \\
(0.0063)\end{array}$ & $\begin{array}{l}-0.0121 \\
(0.0072)\end{array}$ & $\begin{array}{l}-0.0115 \\
(0.0069)\end{array}$ \\
\hline ROA & $\begin{array}{c}-0.1469 * * * \\
(0.0309)\end{array}$ & $\begin{array}{c}-0.1425^{* * *} \\
(0.0437)\end{array}$ & $\begin{array}{c}-0.1671^{* * *} \\
(0.0513)\end{array}$ & $\begin{array}{c}-0.1631^{* * *} \\
(0.0527)\end{array}$ & $\begin{array}{c}-0.1722^{* * *} \\
(0.0528)\end{array}$ \\
\hline Cost-to-income & $\begin{array}{c}-0.0053^{* *} \\
(0.0022)\end{array}$ & $\begin{array}{l}-0.0052 \\
(0.0031)\end{array}$ & $\begin{array}{l}-0.0060 \\
(0.0034)\end{array}$ & $\begin{array}{l}-0.0057 \\
(0.0035)\end{array}$ & $\begin{array}{l}-0.0063 \\
(0.0035)\end{array}$ \\
\hline Tier 1 ratio & $\begin{array}{l}-0.0129 \\
(0.0126)\end{array}$ & $\begin{array}{c}-0.0125 \\
(0.0150)\end{array}$ & $\begin{array}{c}-0.0092 \\
(0.0159)\end{array}$ & $\begin{array}{c}-0.0151 \\
(0.0160)\end{array}$ & $\begin{array}{c}-0.0128 \\
(0.0142)\end{array}$ \\
\hline $\begin{array}{l}N \\
\text { adj. } R^{2}\end{array}$ & $\begin{array}{c}39 \\
0.310\end{array}$ & $\begin{array}{c}39 \\
0.252\end{array}$ & $\begin{array}{c}39 \\
0.207\end{array}$ & $\begin{array}{c}39 \\
0.178\end{array}$ & $\begin{array}{c}39 \\
0.158\end{array}$ \\
\hline
\end{tabular}

Table 6. Geographical complexity and risk: default probability on corporate loan book

Notes: The table reports the estimation of Equation 1. The dependent variable is the logarithm of the probability of default of the firms in the bank's portfolio (In PD). Columns (1) to (5) correspond to the different measures of the independent variable on geographical complexity (Number of countries, Number of foreign affiliates, Number of foreign bank affiliates, Number of affiliates in Africa, Dummy variable for affiliates in Africa). The number of countries counts the countries in which each banking group operates. The number of foreign affiliates considers all branches and subsidiaries abroad, while the number of foreign bank affiliates considers only foreign branches and subsidiaries registered as banks. The number of affiliates (in Africa) counts all affiliates (in Africa). All the independent variables are lagged by one quarter. The sample period goes from 2014 to 2018 . All specifications include time fixed effects. Ordinary Least Squares estimates with robust standard errors clustered at the bank level in parentheses. $* * *, * *$, and ${ }^{*}$ stand for statistical significance at $1 \%, 5 \%$, and $10 \%$, respectively. 


\begin{tabular}{lccccc}
\hline & \multicolumn{5}{c}{ Geographical complexity indicator } \\
\cline { 2 - 6 } & $\begin{array}{c}\text { Number of } \\
\text { countries } \\
(1)\end{array}$ & $\begin{array}{c}\text { Number of foreign } \\
\text { foreign affiliates } \\
(2)\end{array}$ & $\begin{array}{c}\text { Number of foreign } \\
\text { bank affiliates } \\
(3)\end{array}$ & $\begin{array}{c}\text { Number of } \\
\text { affiliates in Africa } \\
(4)\end{array}$ & $\begin{array}{c}\text { Dummy variable } \\
\text { for affiliates in Africa } \\
(5)\end{array}$ \\
\hline Geographical complexity & $0.0527^{* *}$ & $0.0344^{* *}$ & $0.0525^{*}$ & 0.0391 & 0.2572 \\
& $(0.0219)$ & $(0.0157)$ & $(0.0285)$ & $(0.0442)$ & $(0.1968)$ \\
In Assets & 0.0383 & 0.0292 & 0.0325 & 0.0837 & 0.0563 \\
Loans / assets & $(0.0629)$ & $(0.0591)$ & $(0.0563)$ & $(0.0767)$ & $(0.0720)$ \\
ROA & 0.0006 & 0.0009 & 0.0017 & -0.0018 & -0.0027 \\
Cost-to-income & $(0.0063)$ & $(0.0053)$ & $(0.0070)$ & $(0.0070)$ & $(0.0066)$ \\
Tier 1 ratio & -0.1385 & -0.1166 & -0.1540 & -0.1537 & $-0.1702^{*}$ \\
& $(0.1072)$ & $(0.1135)$ & $(0.0962)$ & $(0.0887)$ & $(0.0877)$ \\
\hline$N$ & -0.0028 & -0.0020 & -0.0033 & -0.0032 & -0.0033 \\
adj. $R^{2}$ & $(0.0077)$ & $(0.0072)$ & $(0.0068)$ & $(0.0073)$ & $(0.0075)$ \\
\hline
\end{tabular}

Table 7. Geographical complexity and risk: new NPL / assets

Notes: The table reports the estimation of Equation 1. The dependent variable is the new NPL to total assets ratio. Columns (1) to (5) correspond to the different measures of the independent variable on geographical complexity (Number of countries, Number of foreign affiliates, Number of foreign bank affiliates, Number of affiliates in Africa, Dummy variable for affiliates in Africa). The number of countries counts the countries in which each banking group operates. The number of foreign affiliates considers all branches and subsidiaries abroad, while the number of foreign bank affiliates considers only foreign branches and subsidiaries registered as banks. The number of affiliates (in Africa) counts all affiliates (in Africa). All the independent variables are lagged by one quarter. The sample period goes from 2014 to 2018. All specifications include time fixed effects. Ordinary Least Squares estimates with robust standard errors clustered at the bank level in parentheses. $* * *, * *$, and $*$ stand for statistical significance at $1 \%, 5 \%$, and $10 \%$, respectively. 


\begin{tabular}{lccccc}
\hline & \multicolumn{5}{c}{ Geographical complexity indicator } \\
\cline { 2 - 6 } & $\begin{array}{c}\text { Number of } \\
\text { countries } \\
(1)\end{array}$ & $\begin{array}{c}\text { Number of foreign } \\
\text { foreign affiliates } \\
(2)\end{array}$ & $\begin{array}{c}\text { Number of foreign } \\
\text { bank affiliates } \\
(3)\end{array}$ & $\begin{array}{c}\text { Number of } \\
\text { affiliates in Africa } \\
(4)\end{array}$ & $\begin{array}{c}\text { Dummy variable } \\
\text { for affiliates in Africa } \\
(5)\end{array}$ \\
\hline Geographical complexity & $0.0214^{* * *}$ & $0.0063^{* *}$ & 0.0074 & 0.0205 & 0.0667 \\
In Assets & $(0.0069)$ & $(0.0028)$ & $(0.0060)$ & $(0.0120)$ & $(0.0705)$ \\
& $-0.0806^{* * *}$ & $-0.0668^{* *}$ & $-0.0630^{*}$ & $-0.0650^{* *}$ & $-0.0657^{* * *}$ \\
Loans / assets & $(0.0179)$ & $(0.0260)$ & $(0.0296)$ & $(0.0222)$ & $(0.0202)$ \\
ROA & -0.0008 & -0.0012 & -0.0011 & -0.0019 & -0.0019 \\
Cost-to-income & $(0.0013)$ & $(0.0017)$ & $(0.0017)$ & $(0.0019)$ & $(0.0019)$ \\
Tier 1 ratio & $-0.0416^{*}$ & -0.0429 & -0.0502 & -0.0466 & $-0.0533^{*}$ \\
& $(0.0210)$ & $(0.0261)$ & $(0.0290)$ & $(0.0281)$ & $(0.0260)$ \\
\hline$N$ & -0.0021 & -0.0022 & -0.0024 & -0.0022 & -0.0024 \\
adj. $R^{2}$ & $(0.0014)$ & $(0.0018)$ & $(0.0019)$ & $(0.0019)$ & $(0.0018)$ \\
\hline & -0.0007 & -0.0005 & 0.0003 & -0.0019 & -0.0026 \\
& $(0.0032)$ & $(0.0044)$ & $(0.0046)$ & $(0.0040)$ & $(0.0034)$ \\
\hline
\end{tabular}

Table 8. Geographical complexity and risk: risk-weighted assets to total assets

Notes: The table reports the estimation of Equation 1. The dependent variable is the ratio of risk-weighted assets to total assets. Columns (1) to (5) correspond to the different measures of the independent variable on geographical complexity (Number of countries, Number of foreign affiliates, Number of foreign bank affiliates, Number of affiliates in Africa, Dummy variable for affiliates in Africa). The number of countries counts the countries in which each banking group operates. The number of foreign affiliates considers all branches and subsidiaries abroad, while the number of foreign bank affiliates considers only foreign branches and subsidiaries registered as banks. The number of affiliates (in Africa) counts all affiliates (in Africa). All the independent variables are lagged by one quarter. The sample period goes from 2014 to 2018. All specifications include time fixed effects. Ordinary Least Squares estimates with robust standard errors clustered at the bank level in parentheses. $* * *, * *$, and $*$ stand for statistical significance at $1 \%, 5 \%$, and $10 \%$, respectively. 


\begin{tabular}{|c|c|c|c|c|}
\hline & \multicolumn{4}{|c|}{ Business complexity indicator } \\
\hline & $\begin{array}{l}\text { Number of affiliates } \\
\text { (1) }\end{array}$ & $\begin{array}{c}\text { Share of non-financial } \\
\text { business types } \\
(2)\end{array}$ & $\begin{array}{c}\text { Number of business } \\
\text { types } \\
\text { (3) }\end{array}$ & $\begin{array}{c}\text { HHI business types } \\
\text { (4) }\end{array}$ \\
\hline Business complexity & $\begin{array}{c}-0.0139^{* * *} \\
(0.0041)\end{array}$ & $\begin{array}{c}-2.3905 \\
(2.1681)\end{array}$ & $\begin{array}{l}-0.1660 \\
(0.1115)\end{array}$ & $\begin{array}{c}0.3179 \\
(0.5250)\end{array}$ \\
\hline In Assets & $\begin{array}{c}0.4328^{* * *} \\
(0.1008)\end{array}$ & $\begin{array}{l}0.5013^{*} \\
(0.2579)\end{array}$ & $\begin{array}{l}0.4554^{* *} \\
(0.1466)\end{array}$ & $\begin{array}{c}0.3456^{* *} \\
(0.1308)\end{array}$ \\
\hline Loans / assets & $\begin{array}{c}0.0073 \\
(0.0069)\end{array}$ & $\begin{array}{l}-0.0326 \\
(0.0204)\end{array}$ & $\begin{array}{c}0.0029 \\
(0.0080)\end{array}$ & $\begin{array}{c}0.0037 \\
(0.0086)\end{array}$ \\
\hline ROA & $\begin{array}{c}0.0147 \\
(0.1531)\end{array}$ & $\begin{array}{l}-0.0860 \\
(0.1668)\end{array}$ & $\begin{array}{c}0.1136 \\
(0.1577)\end{array}$ & $\begin{array}{c}0.1125 \\
(0.1886)\end{array}$ \\
\hline Cost-to-income & $\begin{array}{c}0.0090 \\
(0.0070)\end{array}$ & $\begin{array}{c}0.0193^{* * *} \\
(0.0053)\end{array}$ & $\begin{array}{l}0.0156^{*} \\
(0.0078)\end{array}$ & $\begin{array}{c}0.0134 \\
(0.0084)\end{array}$ \\
\hline Tier 1 ratio & $\begin{array}{c}0.0693^{* * *} \\
(0.0189)\end{array}$ & $\begin{array}{c}0.0290 \\
(0.0210)\end{array}$ & $\begin{array}{c}0.0632^{* * *} \\
(0.0166)\end{array}$ & $\begin{array}{c}0.0463 \\
(0.0279)\end{array}$ \\
\hline $\begin{array}{l}N \\
\text { adj. } R^{2}\end{array}$ & $\begin{array}{c}33 \\
0.320\end{array}$ & $\begin{array}{c}26 \\
0.251\end{array}$ & $\begin{array}{c}33 \\
0.274\end{array}$ & $\begin{array}{c}32 \\
0.174\end{array}$ \\
\hline
\end{tabular}

Table 9. Business complexity and risk: z-score

Notes: The table reports the estimation of Equation 1. The dependent variable is the logarithm of the z-score calculated over eight quarters (In Z-score). The In z-score is computed as the logarithm of the inverse of the average return on assets in a given period plus the equity to assets ratio of the bank, divided by the standard deviation of the return on assets in the last 8 quarters. Columns (1) to (4) correspond to the different measures of the independent variable on business complexity (Number of affiliates, Share of non-financial business types, Number of business types, HHI business types). The share of non-financial business types captures the percentage of the group's non-financial activities. The $\mathrm{HHI}$ for business types refers to the Herfindahl-Hirschman Index for business types and equals 0 when a group only operates in one business type. All the independent variables are lagged by one quarter. The sample period goes from 2014 to 2018. All specifications include time fixed effects. Ordinary Least Squares estimates with robust standard errors clustered at the bank level in parentheses. $* * *, * *$, and $*$ stand for statistical significance at $1 \%, 5 \%$, and $10 \%$, respectively. 


\begin{tabular}{|c|c|c|c|c|}
\hline & \multicolumn{4}{|c|}{ Business complexity indicator } \\
\hline & $\begin{array}{c}\text { Number of affiliates } \\
\text { (1) }\end{array}$ & $\begin{array}{c}\text { Share of non-financial } \\
\text { business types } \\
(2)\end{array}$ & $\begin{array}{c}\text { Number of business } \\
\text { types } \\
(3)\end{array}$ & $\begin{array}{c}\text { HHI business types } \\
\text { (4) }\end{array}$ \\
\hline Business complexity & $\begin{array}{c}0.0031 \\
(0.0032)\end{array}$ & $\begin{array}{c}0.3684 \\
(0.7027)\end{array}$ & $\begin{array}{c}0.0200 \\
(0.0472)\end{array}$ & $\begin{array}{c}0.4160 \\
(0.2934)\end{array}$ \\
\hline In Assets & $\begin{array}{l}-0.0571 \\
(0.0573)\end{array}$ & $\begin{array}{c}0.0270 \\
(0.1056)\end{array}$ & $\begin{array}{l}-0.0530 \\
(0.0636)\end{array}$ & $\begin{array}{c}0.0110 \\
(0.0677)\end{array}$ \\
\hline Loans / assets & $\begin{array}{l}-0.0121 \\
(0.0073)\end{array}$ & $\begin{array}{c}0.0002 \\
(0.0063)\end{array}$ & $\begin{array}{l}-0.0115 \\
(0.0070)\end{array}$ & $\begin{array}{l}-0.0152 \\
(0.0088)\end{array}$ \\
\hline ROA & $\begin{array}{c}-0.1529^{* * *} \\
(0.0484)\end{array}$ & $\begin{array}{c}-0.0850^{*} \\
(0.0390)\end{array}$ & $\begin{array}{c}-0.1735^{* * *} \\
(0.0526)\end{array}$ & $\begin{array}{c}-0.2040^{* * *} \\
(0.0533)\end{array}$ \\
\hline Cost-to-income & $\begin{array}{l}-0.0051 \\
(0.0034)\end{array}$ & $\begin{array}{c}0.0014 \\
(0.0022)\end{array}$ & $\begin{array}{l}-0.0062 \\
(0.0036)\end{array}$ & $\begin{array}{c}-0.0071^{* *} \\
(0.0031)\end{array}$ \\
\hline Tier 1 ratio & $\begin{array}{l}-0.0155 \\
(0.0179)\end{array}$ & $\begin{array}{c}0.0052 \\
(0.0074)\end{array}$ & $\begin{array}{l}-0.0138 \\
(0.0173)\end{array}$ & $\begin{array}{l}-0.0180 \\
(0.0166)\end{array}$ \\
\hline $\begin{array}{l}N \\
\text { adj. } R^{2}\end{array}$ & $\begin{array}{c}39 \\
0.173\end{array}$ & $\begin{array}{c}29 \\
0.630\end{array}$ & $\begin{array}{c}39 \\
0.161\end{array}$ & $\begin{array}{c}35 \\
0.146\end{array}$ \\
\hline
\end{tabular}

Table 10. Risk and business complexity: logarithm of the probability of default of the firms in the bank's portfolio

Notes: The table reports the estimation of Equation 1. The dependent variable is the logarithm of the probability of default of the firms in the bank's portfolio (In PD). Columns (1) to (4) correspond to the different measures of the independent variable on business complexity (Number of affiliates, Share of non-financial business types, Number of business types, HHI business types). The share of non-financial business types captures the percentage of the group's non-financial activities. The HHI for business types refers to the Herfindahl-Hirschman Index for business types and equals 0 when a group only operates in one business type. All the independent variables are lagged by one quarter. The sample period goes from 2014 to 2018. All specifications include time fixed effects. Ordinary Least Squares estimates with robust standard errors clustered at the bank level in parentheses. ***, $* *$, and ${ }^{*}$ stand for statistical significance at $1 \%, 5 \%$, and $10 \%$, respectively. 


\begin{tabular}{|c|c|c|c|c|}
\hline & \multicolumn{4}{|c|}{ Business complexity indicator } \\
\hline & $\begin{array}{c}\text { Number of affiliates } \\
\text { (1) }\end{array}$ & $\begin{array}{c}\text { Share of non-financial } \\
\text { business types } \\
(2)\end{array}$ & $\begin{array}{c}\text { Number of business } \\
\text { types } \\
\text { (3) }\end{array}$ & $\begin{array}{c}\text { HHI business types } \\
\text { (4) }\end{array}$ \\
\hline Business complexity & $\begin{array}{c}0.0013 \\
(0.0059)\end{array}$ & $\begin{array}{c}0.6727 \\
(1.3867)\end{array}$ & $\begin{array}{l}-0.0721 \\
(0.0477)\end{array}$ & $\begin{array}{l}-0.1681 \\
(0.5414)\end{array}$ \\
\hline In Assets & $\begin{array}{c}0.1003 \\
(0.0658)\end{array}$ & $\begin{array}{l}0.3681^{*} \\
(0.1742)\end{array}$ & $\begin{array}{l}0.1563^{* *} \\
(0.0709)\end{array}$ & $\begin{array}{c}0.0653 \\
(0.1076)\end{array}$ \\
\hline Loans / assets & $\begin{array}{l}-0.0015 \\
(0.0069)\end{array}$ & $\begin{array}{c}-0.0174 \\
(0.0114)\end{array}$ & $\begin{array}{l}-0.0011 \\
(0.0066)\end{array}$ & $\begin{array}{c}0.0013 \\
(0.0092)\end{array}$ \\
\hline ROA & $\begin{array}{l}-0.1547 \\
(0.0975)\end{array}$ & $\begin{array}{c}-0.1194 \\
(0.1261)\end{array}$ & $\begin{array}{l}-0.1576^{*} \\
(0.0830)\end{array}$ & $\begin{array}{c}-0.1730^{*} \\
(0.0838)\end{array}$ \\
\hline Cost-to-income & $\begin{array}{c}-0.0032 \\
(0.0077)\end{array}$ & $\begin{array}{c}0.0021 \\
(0.0082)\end{array}$ & $\begin{array}{c}-0.0042 \\
(0.0069)\end{array}$ & $\begin{array}{c}-0.0028 \\
(0.0060)\end{array}$ \\
\hline Tier 1 ratio & $\begin{array}{c}0.0110 \\
(0.0181)\end{array}$ & $\begin{array}{c}0.0150 \\
(0.0171)\end{array}$ & $\begin{array}{c}0.0163 \\
(0.0170)\end{array}$ & $\begin{array}{c}0.0186 \\
(0.0196)\end{array}$ \\
\hline$N$ & 39 & 29 & 39 & 35 \\
\hline adj. $R^{2}$ & 0.160 & 0.299 & 0.180 & 0.186 \\
\hline
\end{tabular}

Table 11. Business complexity and risk: new NPL / assets

Notes: The table reports the estimation of Equation 1. The dependent variable is the new NPL to total assets ratio. Columns (1) to (4) correspond to the different measures of the independent variable on business complexity (Number of affiliates, Share of non-financial business types, Number of business types, $\mathrm{HHI}$ business types). The share of non-financial business types captures the percentage of the group's non-financial activities. The HHI for business types refers to the Herfindahl-Hirschman Index for business types and equals 0 when a group only operates in one business type. All the independent variables are lagged by one quarter. The sample period goes from 2014 to 2018. All specifications include time fixed effects. Ordinary Least Squares estimates with robust standard errors clustered at the bank level in parentheses. $* * *, * *$, and $*$ stand for statistical significance at $1 \%, 5 \%$, and $10 \%$, respectively. 


\begin{tabular}{lcccc}
\hline & \multicolumn{4}{c}{ Business complexity indicator } \\
\cline { 2 - 5 } & $(1)$ & $\begin{array}{c}\text { Number of affiliates } \\
\text { Share of non-financial } \\
\text { business types } \\
(2)\end{array}$ & $\begin{array}{c}\text { Number of business } \\
\text { types } \\
(3)\end{array}$ & HHI business types \\
\hline Business complexity & 0.0001 & -0.2522 & -0.0046 & $(4)$ \\
In Assets & $(0.0011)$ & $(0.1850)$ & $(0.0164)$ & 0.1705 \\
& $-0.0532^{*}$ & $0.0568^{*}$ & -0.0492 & $(0.1200)$ \\
Loans / assets & $(0.0272)$ & $(0.0285)$ & $(0.0278)$ & -0.0266 \\
& -0.0016 & -0.0015 & -0.0015 & -0.0034 \\
ROA & $(0.0020)$ & $(0.0016)$ & $(0.0020)$ & $(0.0020)$ \\
& $-0.0505^{*}$ & -0.0164 & $-0.0511^{*}$ & $-0.0653^{* *}$ \\
Cost-to-income & $(0.0243)$ & $(0.0142)$ & $(0.0286)$ & $(0.0234)$ \\
& -0.0025 & 0.0010 & -0.0025 & $-0.0029^{*}$ \\
Tier 1 ratio & $(0.0017)$ & $(0.0009)$ & $(0.0019)$ & $(0.0015)$ \\
& -0.0007 & 0.0044 & -0.0003 & -0.0028 \\
& $(0.0048)$ & $(0.0036)$ & $(0.0048)$ & $(0.0042)$ \\
\hline$N$ & 39 & 29 & 39 & 35 \\
adj. $R^{2}$ & 0.202 & 0.310 & 0.204 & 0.285 \\
\hline
\end{tabular}

Table 12. Business complexity and risk: risk weighted assets to total assets ratio

Notes: The table reports the estimation of Equation 1 . The dependent variable is the ratio of risk-weighted assets to total assets. Columns (1) to (4) correspond to the different measures of the independent variable on business complexity (Number of affiliates, Share of non-financial business types, Number of business types, HHI business types). The share of non-financial business types captures the percentage of the group's non-financial activities. The HHI for business types refers to the Herfindahl-Hirschman Index for business types and equals 0 when a group only operates in one business type. All the independent variables are lagged by one quarter. The sample period goes from 2014 to 2018. All specifications include time fixed effects. Ordinary Least Squares estimates with robust standard errors clustered at the bank level in parentheses. ${ }^{* *}, * *$, and $*$ stand for statistical significance at $1 \%, 5 \%$, and $10 \%$, respectively. 


\begin{tabular}{lccccc}
\hline & \multicolumn{5}{c}{ Geographical complexity indicator } \\
\cline { 2 - 6 } & $\begin{array}{c}\text { Number of } \\
\text { countries } \\
(1)\end{array}$ & $\begin{array}{c}\text { Number of foreign } \\
\text { foreign affiliates } \\
(2)\end{array}$ & $\begin{array}{c}\text { Number of foreign } \\
\text { bank affiliates } \\
(3)\end{array}$ & $\begin{array}{c}\text { Number of } \\
\text { affiliates in Africa } \\
(4)\end{array}$ & $\begin{array}{c}\text { Dummy variable } \\
\text { for affiliates in Africa } \\
(5)\end{array}$ \\
\hline Geographical complexity & $0.1051^{*}$ & $0.0610^{*}$ & 0.1007 & $0.2061^{* *}$ & 1.7462 \\
& $(0.0561)$ & $(0.0357)$ & $(0.0639)$ & $(0.1007)$ & $(1.1552)$ \\
Loans / assets & 0.0124 & 0.0082 & $0.0138^{* *}$ & 0.0076 & 0.0017 \\
& $(0.0087)$ & $(0.0082)$ & $(0.0069)$ & $(0.0055)$ & $(0.0048)$ \\
ROA & 0.1723 & 0.1786 & 0.1011 & 0.1920 & 0.1322 \\
& $(0.1872)$ & $(0.1997)$ & $(0.1810)$ & $(0.1247)$ & $(0.0860)$ \\
Cost-to-income & $0.0177^{* *}$ & $0.0242^{*}$ & $0.0197^{*}$ & $0.0141^{* *}$ & 0.0114 \\
& $(0.0088)$ & $(0.0124)$ & $(0.0101)$ & $(0.0059)$ & $(0.0076)$ \\
Tier 1 ratio & $0.0479^{* *}$ & $0.0444^{* *}$ & $0.0682^{* * *}$ & $0.0352^{* *}$ & -0.0177 \\
& $(0.0186)$ & $(0.0208)$ & $(0.0125)$ & $(0.0170)$ & $(0.0509)$ \\
In Assets & 0.0895 & 0.0569 & 0.0685 & 0.1232 & -0.1221 \\
& $(0.1743)$ & $(0.2053)$ & $(0.2050)$ & $(0.1505)$ & $(0.3038)$ \\
\hline First-stage F-stat. & $14.2489^{* * *}$ & $15.7643^{* * *}$ & $11.3370^{* * *}$ & $29.7177^{* * *}$ & 0.6539 \\
\hline$N$ & 33 & 33 & 33 & 33 & 33 \\
\hline
\end{tabular}

Table 13. Geographical complexity and risk: z-score

Notes: The table reports the estimation of Equation 1, when using a two-stages least square estimation where the first-stage is estimated using Equation (2). The dependent variable is the logarithm of the z-score calculated over eight quarters (In Z-score). The In z-score is computed as the logarithm of the inverse of the average return on assets in a given period plus the equity to assets ratio of the bank, divided by the standard deviation of the return on assets in the last 8 quarters. Columns (1) to (5) correspond to the different measures of the independent variable on geographical complexity (Number of locations, Number of foreign affiliates, Number of foreign bank affiliates, Number of affiliates in Africa, Dummy variable for affiliates in Africa). The number of countries counts the countries in which each banking group operates. The number of foreign affiliates considers all branches and subsidiaries abroad, while the number of foreign bank affiliates considers only foreign branches and subsidiaries registered as banks. The number of affiliates (in Africa) counts all affiliates (in Africa). All the independent variables are lagged by one quarter. The sample period goes from 2014 to 2018. All specifications include time fixed effects. Two-stage least squares estimates with robust standard errors clustered at the bank level in parentheses. $* * *, * *$, and ${ }^{*}$ stand for statistical significance at $1 \%, 5 \%$, and $10 \%$, respectively. 


\begin{tabular}{lccccc}
\hline & \multicolumn{5}{c}{ Geographical complexity indicator } \\
\cline { 2 - 6 } & $\begin{array}{c}\text { Number of } \\
\text { countries } \\
(1)\end{array}$ & $\begin{array}{c}\text { Number of foreign } \\
\text { foreign affiliates } \\
(2)\end{array}$ & $\begin{array}{c}\text { Number of foreign } \\
\text { bank affiliates } \\
(3)\end{array}$ & $\begin{array}{c}\text { Number of } \\
\text { affiliates in Africa } \\
(4)\end{array}$ & $\begin{array}{c}\text { Dummy variable } \\
\text { for affiliates in Africa } \\
(5)\end{array}$ \\
\hline Geographical complexity & 0.0231 & 0.0108 & 0.0237 & 0.0480 & 0.3140 \\
Loans / assets & $(0.0287)$ & $(0.0144)$ & $(0.0295)$ & $(0.0607)$ & $(0.4991)$ \\
& $-0.0106^{* *}$ & $-0.0108^{* *}$ & $-0.0101^{*}$ & $-0.0123^{* *}$ & $-0.0133^{*}$ \\
ROA & $(0.0051)$ & $(0.0055)$ & $(0.0056)$ & $(0.0061)$ & $(0.0074)$ \\
Cost-to-income & $-0.1614^{* * *}$ & $-0.1575^{* * *}$ & $-0.1681^{* * *}$ & $-0.1609^{* * *}$ & $-0.1811^{* * *}$ \\
Tier 1 ratio & $(0.0349)$ & $(0.0414)$ & $(0.0414)$ & $(0.0480)$ & $(0.0506)$ \\
& $-0.0059^{* *}$ & $-0.0057^{* *}$ & $-0.0061^{* *}$ & $-0.0056^{*}$ & -0.0057 \\
In Assets & $(0.0023)$ & $(0.0027)$ & $(0.0028)$ & $(0.0030)$ & $(0.0036)$ \\
& -0.0128 & -0.0126 & -0.0099 & -0.0157 & -0.0222 \\
\hline First-stage F-stat & $(0.0123)$ & $(0.0132)$ & $(0.0154)$ & $(0.0129)$ & $(0.0187)$ \\
\hline$N$ & -0.0699 & -0.0641 & -0.0734 & -0.0690 & -0.1022 \\
& $(0.0554)$ & $(0.0533)$ & $(0.0625)$ & $(0.0565)$ & $(0.1032)$ \\
\hline
\end{tabular}

Table 14. Geographical complexity and risk: default probability on corporate loan book

Notes: The table reports the estimation of Equation 1, when using a two-stages least square estimation where the first-stage is estimated using Equation (2). The dependent variable is the logarithm of the probability of default of the firms in the bank's portfolio (In PD). Columns (1) to (5) correspond to the different measures of the independent variable on geographical complexity (Number of locations, Number of foreign affiliates, Number of foreign bank affiliates, Number of affiliates in Africa, Dummy variable for affiliates in Africa). The number of countries counts the countries in which each banking group operates. The number of foreign affiliates considers all branches and subsidiaries abroad, while the number of foreign bank affiliates considers only foreign branches and subsidiaries registered as banks. The number of affiliates (in Africa) counts all affiliates (in Africa). All the independent variables are lagged by one quarter. The sample period goes from 2014 to 2018. All specifications include time fixed effects. Two-stage least squares estimates with robust standard errors clustered at the bank level in parentheses. $* * *, * *$, and ${ }^{*}$ stand for statistical significance at $1 \%, 5 \%$, and $10 \%$, respectively. 


\begin{tabular}{|c|c|c|c|c|c|}
\hline & \multicolumn{5}{|c|}{ Geographical complexity indicator } \\
\hline & $\begin{array}{l}\text { Number of } \\
\text { countries } \\
\text { (1) }\end{array}$ & $\begin{array}{l}\text { Number of foreign } \\
\text { foreign affiliates } \\
\text { (2) }\end{array}$ & $\begin{array}{l}\text { Number of foreign } \\
\text { bank affiliates } \\
\text { (3) }\end{array}$ & $\begin{array}{c}\text { Number of } \\
\text { affiliates in Africa } \\
\text { (4) }\end{array}$ & $\begin{array}{l}\text { Dummy variable } \\
\text { for affiliates in Africa } \\
\text { (5) }\end{array}$ \\
\hline Geographical complexity & $\begin{array}{c}0.2293^{* * *} \\
(0.0714)\end{array}$ & $\begin{array}{c}0.1072^{* * *} \\
(0.0391)\end{array}$ & $\begin{array}{c}0.2356^{* * *} \\
(0.0800)\end{array}$ & $\begin{array}{c}0.4774^{* * *} \\
(0.1081)\end{array}$ & $\begin{array}{c}3.1209 \\
(2.2441)\end{array}$ \\
\hline Loans / assets & $\begin{array}{c}0.0067 \\
(0.0091)\end{array}$ & $\begin{array}{c}0.0052 \\
(0.0072)\end{array}$ & $\begin{array}{c}0.0118 \\
(0.0079)\end{array}$ & $\begin{array}{c}-0.0094 \\
(0.0081)\end{array}$ & $\begin{array}{c}-0.0194 \\
(0.0188)\end{array}$ \\
\hline ROA & $\begin{array}{l}-0.0572 \\
(0.1826)\end{array}$ & $\begin{array}{l}-0.0186 \\
(0.1819)\end{array}$ & $\begin{array}{l}-0.1234 \\
(0.1678)\end{array}$ & $\begin{array}{l}-0.0518 \\
(0.1541)\end{array}$ & $\begin{array}{c}-0.2529 \\
(0.2591)\end{array}$ \\
\hline Cost-to-income & $\begin{array}{c}0.0004 \\
(0.0108)\end{array}$ & $\begin{array}{c}0.0017 \\
(0.0094)\end{array}$ & $\begin{array}{l}-0.0018 \\
(0.0092)\end{array}$ & $\begin{array}{c}0.0029 \\
(0.0096)\end{array}$ & $\begin{array}{c}0.0017 \\
(0.0182)\end{array}$ \\
\hline Tier 1 ratio & $\begin{array}{c}0.0112 \\
(0.0195)\end{array}$ & $\begin{array}{c}0.0132 \\
(0.0160)\end{array}$ & $\begin{array}{l}0.0400^{*} \\
(0.0233)\end{array}$ & $\begin{array}{l}-0.0176 \\
(0.0207)\end{array}$ & $\begin{array}{c}-0.0823 \\
(0.0837)\end{array}$ \\
\hline In Assets & $\begin{array}{l}-0.1946 \\
(0.1230)\end{array}$ & $\begin{array}{l}-0.1373 \\
(0.0910)\end{array}$ & $\begin{array}{c}-0.2296^{* *} \\
(0.1162)\end{array}$ & $\begin{array}{c}-0.1853^{* *} \\
(0.0916)\end{array}$ & $\begin{array}{l}-0.5159 \\
(0.4636)\end{array}$ \\
\hline First-stage F-stat & $7.7410^{* *}$ & $11.8872^{* * *}$ & $4.5571^{*}$ & $8.1762^{* *}$ & 1.4662 \\
\hline$N$ & 39 & 39 & 39 & 39 & 39 \\
\hline
\end{tabular}

Table 15. Geographical complexity and risk: new NPL / assets

Notes: The table reports the estimation of Equation 1, when using a two-stages least square estimation where the first-stage is estimated using Equation (2). The dependent variable is the new NPL to total assets ratio. Columns (1) to (5) correspond to the different measures of the independent variable on geographical complexity (Number of locations, Number of foreign affiliates, Number of foreign bank affiliates, Number of affiliates in Africa, Dummy variable for affiliates in Africa). The number of countries counts the countries in which each banking group operates. The number of foreign affiliates considers all branches and subsidiaries abroad, while the number of foreign bank affiliates considers only foreign branches and subsidiaries registered as banks. The number of affiliates (in Africa) counts all affiliates (in Africa). All the independent variables are lagged by one quarter. The sample period goes from 2014 to 2018. All specifications include time fixed effects. Two-stage least squares estimates with robust standard errors clustered at the bank level in parentheses. $* * *$, $* *$, and ${ }^{*}$ stand for statistical significance at $1 \%, 5 \%$, and $10 \%$, respectively. 


\begin{tabular}{lccccc}
\hline & \multicolumn{5}{c}{ Geographical complexity indicator } \\
\cline { 2 - 6 } & $\begin{array}{c}\text { Number of } \\
\text { countries } \\
(1)\end{array}$ & $\begin{array}{c}\text { Number of foreign } \\
\text { foreign affiliates } \\
(2)\end{array}$ & $\begin{array}{c}\text { Number of foreign } \\
\text { bank affiliates } \\
(3)\end{array}$ & $\begin{array}{c}\text { Number of } \\
\text { affiliates in Africa } \\
(4)\end{array}$ & $\begin{array}{c}\text { Dummy variable } \\
\text { for affiliates in Africa } \\
(5)\end{array}$ \\
\hline Geographical complexity & 0.0089 & 0.0042 & 0.0092 & 0.0185 & 0.1212 \\
Loans / assets & $(0.0112)$ & $(0.0057)$ & $(0.0120)$ & $(0.0249)$ & $(0.1687)$ \\
ROA & -0.0012 & -0.0013 & -0.0010 & -0.0019 & -0.0023 \\
Cost-to-income & $(0.0015)$ & $(0.0016)$ & $(0.0018)$ & $(0.0016)$ & $(0.0018)$ \\
Tier 1 ratio & $-0.0473^{* *}$ & $-0.0458^{*}$ & $-0.0499^{*}$ & $-0.0471^{*}$ & $-0.0549^{* * *}$ \\
& $(0.0221)$ & $(0.0259)$ & $(0.0256)$ & $(0.0254)$ & $(0.0206)$ \\
In Assets & -0.0023 & -0.0023 & -0.0024 & -0.0022 & -0.0023 \\
& $(0.0014)$ & $(0.0017)$ & $(0.0017)$ & $(0.0017)$ & $(0.0016)$ \\
\hline First-stage F-stat & -0.0006 & -0.0006 & 0.0005 & -0.0018 & -0.0043 \\
& $(0.0033)$ & $(0.0038)$ & $(0.0049)$ & $(0.0033)$ & $(0.0051)$ \\
$N$ & $-0.0641^{* * *}$ & $-0.0619^{* * *}$ & $-0.0655^{* * *}$ & $-0.0638^{* * *}$ & $-0.0766^{* *}$ \\
& $(0.0217)$ & $(0.0220)$ & $(0.0249)$ & $(0.0225)$ & $(0.0329)$ \\
\hline
\end{tabular}

Table 16. Geographical complexity and risk: risk-weighted assets to total assets

Notes: The table reports the estimation of Equation 1, when using a two-stages least square estimation where the first-stage is estimated using Equation (2). The dependent variable is the ratio of risk-weighted assets to total assets. Columns (1) to (5) correspond to the different measures of the independent variable on geographical complexity (Number of countries, Number of foreign affiliates, Number of foreign bank affiliates, Number of affiliates in Africa, Dummy variable for affiliates in Africa). The number of countries counts the countries in which each banking group operates. The number of foreign affiliates considers all branches and subsidiaries abroad, while the number of foreign bank affiliates considers only foreign branches and subsidiaries registered as banks. The number of affiliates (in Africa) counts all affiliates (in Africa). All the independent variables are lagged by one quarter. The sample period goes from 2014 to 2018. All specifications include time fixed effects. Two-stage least squares estimates with robust standard errors clustered at the bank level in parentheses. $* * *, * *$, and ${ }^{*}$ stand for statistical significance at $1 \%, 5 \%$, and $10 \%$, respectively. 


\begin{tabular}{|c|c|c|c|c|}
\hline & \multicolumn{4}{|c|}{ Business complexity indicator } \\
\hline & $\begin{array}{l}\text { Number of affiliates } \\
\text { (1) }\end{array}$ & $\begin{array}{c}\text { Share of non-financial } \\
\text { business types } \\
\text { (2) }\end{array}$ & $\begin{array}{c}\text { Number of business } \\
\text { types } \\
\text { (3) }\end{array}$ & $\begin{array}{c}\text { HHI business types } \\
\text { (4) }\end{array}$ \\
\hline Business complexity & $\begin{array}{c}-1.0623 \\
(21.7628)\end{array}$ & $\begin{array}{l}-6.7087^{*} \\
(3.7034)\end{array}$ & $\begin{array}{c}1.6958 \\
(6.8611)\end{array}$ & $\begin{array}{c}7.8397 \\
(11.9839)\end{array}$ \\
\hline Loans / assets & $\begin{array}{c}0.2151 \\
(4.1602)\end{array}$ & $\begin{array}{l}-0.0373^{*} \\
(0.0195)\end{array}$ & $\begin{array}{c}0.0217 \\
(0.0566)\end{array}$ & $\begin{array}{l}-0.0160 \\
(0.0413)\end{array}$ \\
\hline ROA & $\begin{array}{c}-7.4390 \\
(152.1972)\end{array}$ & $\begin{array}{l}-0.2577 \\
(0.2879)\end{array}$ & $\begin{array}{c}0.1132 \\
(0.5112)\end{array}$ & $\begin{array}{l}-0.3563 \\
(0.5629)\end{array}$ \\
\hline Cost-to-income & $\begin{array}{l}-0.4422 \\
(9.2865)\end{array}$ & $\begin{array}{l}0.0155^{*} \\
(0.0084)\end{array}$ & $\begin{array}{c}0.0082 \\
(0.0450)\end{array}$ & $\begin{array}{c}-0.0159 \\
(0.0389)\end{array}$ \\
\hline Tier 1 ratio & $\begin{array}{c}1.4222 \\
(27.8413)\end{array}$ & $\begin{array}{c}0.0390^{* * *} \\
(0.0122)\end{array}$ & $\begin{array}{l}-0.0696 \\
(0.5457)\end{array}$ & $\begin{array}{c}-0.0723 \\
(0.1976)\end{array}$ \\
\hline In Assets & $\begin{array}{c}8.6595 \\
(174.1964)\end{array}$ & $\begin{array}{c}0.7086^{* *} \\
(0.2884)\end{array}$ & $\begin{array}{l}-1.0207 \\
(5.2992)\end{array}$ & $\begin{array}{c}0.4969 \\
(0.5554)\end{array}$ \\
\hline First-stage F-stat & 0.0015 & 3.2543 & 0.0503 & 0.2420 \\
\hline$N$ & 33 & 26 & 32 & 33 \\
\hline
\end{tabular}

Table 17. Business complexity and risk: z-score

Notes: The table reports the estimation of Equation 1, when using a two-stages least square estimation where the first-stage is estimated using Equation (2). The dependent variable is the logarithm of the z-score calculated over eight quarters (In Z-score). The In z-score is computed as the logarithm of the inverse of the average return on assets in a given period plus the equity to assets ratio of the bank, divided by the standard deviation of the return on assets in the last 8 quarters. Columns (1) to (4) correspond to the different measures of the independent variable on business complexity (Number of affiliates, Share of non-financial business types, Number of business types, HHI business types). The share of non-financial business types captures the percentage of the group's non-financial activities. The HHI for business types refers to the Herfindahl-Hirschman Index for business types and equals 0 when a group only operates in one business type. All the independent variables are lagged by one quarter. The sample period goes from 2014 to 2018 . All specifications include time fixed effects. Two-stage least squares estimates with robust standard errors clustered at the bank level in parentheses. ${ }^{* * *}, * *$, and ${ }^{*}$ stand for statistical significance at $1 \%, 5 \%$, and $10 \%$, respectively. 


\begin{tabular}{|c|c|c|c|c|}
\hline & \multicolumn{4}{|c|}{ Business complexity indicator } \\
\hline & $\begin{array}{c}\text { Number of affiliates } \\
\text { (1) }\end{array}$ & $\begin{array}{c}\text { Share of non-financial } \\
\text { business types } \\
(2)\end{array}$ & $\begin{array}{c}\text { Number of business } \\
\text { types } \\
\text { (3) }\end{array}$ & $\begin{array}{c}\text { HHI business types } \\
\text { (4) }\end{array}$ \\
\hline Business complexity & $\begin{array}{c}0.0222 \\
(0.0516)\end{array}$ & $\begin{array}{c}-3.1813 \\
(2.1923)\end{array}$ & $\begin{array}{c}0.2461 \\
(0.5832)\end{array}$ & $\begin{array}{c}0.6549 \\
(1.6773)\end{array}$ \\
\hline Loans / assets & $\begin{array}{c}-0.0163 \\
(0.0146)\end{array}$ & $\begin{array}{l}-0.0042 \\
(0.0076)\end{array}$ & $\begin{array}{l}-0.0116^{*} \\
(0.0061)\end{array}$ & $\begin{array}{l}-0.0160 \\
(0.0106)\end{array}$ \\
\hline ROA & $\begin{array}{l}-0.0350 \\
(0.3597)\end{array}$ & $\begin{array}{c}-0.2072^{* *} \\
(0.0931)\end{array}$ & $\begin{array}{c}-0.1896^{* *} \\
(0.0871)\end{array}$ & $\begin{array}{l}-0.2224^{*} \\
(0.1319)\end{array}$ \\
\hline Cost-to-income & $\begin{array}{c}0.0021 \\
(0.0219)\end{array}$ & $\begin{array}{l}-0.0026 \\
(0.0047)\end{array}$ & $\begin{array}{c}-0.0048 \\
(0.0048)\end{array}$ & $\begin{array}{c}-0.0075^{*} \\
(0.0045)\end{array}$ \\
\hline Tier 1 ratio & $\begin{array}{c}-0.0334 \\
(0.0555)\end{array}$ & $\begin{array}{c}0.0077 \\
(0.0093)\end{array}$ & $\begin{array}{c}-0.0264 \\
(0.0395)\end{array}$ & $\begin{array}{c}-0.0209 \\
(0.0254)\end{array}$ \\
\hline In Assets & $\begin{array}{c}-0.1657 \\
(0.2849)\end{array}$ & $\begin{array}{c}0.1933 \\
(0.2038)\end{array}$ & $\begin{array}{c}-0.2051 \\
(0.4137)\end{array}$ & $\begin{array}{c}0.0161 \\
(0.0704)\end{array}$ \\
\hline First-stage F-stat & 0.1605 & 1.5815 & 0.1576 & 0.6968 \\
\hline$N$ & 39 & 29 & 39 & 35 \\
\hline
\end{tabular}

Table 18. Business complexity and risk: default probability on corporate loan book

Notes: The table reports the estimation of Equation 1, when using a two-stages least square estimation where the first-stage is estimated using Equation (2). The dependent variable is the logarithm of the probability of default of the firms in the bank's portfolio (In PD). Columns (1) to (4) correspond to the different measures of the independent variable on business complexity (Number of affiliates, Share of non-financial business types, Number of business types, HHI business types). The share of non-financial business types captures the percentage of the group's non-financial activities. The HHI for business types refers to the Herfindahl-Hirschman Index for business types and equals 0 when a group only operates in one business type. All the independent variables are lagged by one quarter. The sample period goes from 2014 to 2018. All specifications include time fixed effects. Two-stage least squares estimates with robust standard errors clustered at the bank level in parentheses. $* * *, * *$, and $*$ stand for statistical significance at $1 \%, 5 \%$, and $10 \%$, respectively. 


\begin{tabular}{lcccc}
\hline & \multicolumn{4}{c}{ Business complexity indicator } \\
\cline { 2 - 5 } & $(1)$ & -13.6915 & 2.4464 & $(4)$ \\
\hline Business complexity & 0.2209 & $(11.8372)$ & $(5.1716)$ & 8.5468 \\
& $(0.4641)$ & -0.0351 & -0.0029 & $(9.3397)$ \\
Loans / assets & -0.0499 & $(0.0309)$ & $(0.0252)$ & -0.0285 \\
& $(0.1226)$ & -0.6139 & -0.3369 & $(0.0345)$ \\
ROA & 1.1996 & $(0.3842)$ & $(0.6344)$ & -0.8444 \\
Cost-to-incomes & $(2)$ & 0.0112 & $(0.6279)$ \\
Tier 1 ratio & $(3.4002)$ & -0.0138 & $(0.0469)$ & -0.0196 \\
& 0.0796 & $(0.0161)$ & -0.1247 & $(0.0241)$ \\
In Assets & $(0.2030)$ & 0.0252 & $(0.3288)$ & -0.0892 \\
& -0.1943 & $(0.0339)$ & -1.5387 & $(0.1182)$ \\
& $(0.4921)$ & 1.0410 & $(3.4642)$ & 0.2496 \\
First-stage F-stat & -1.1470 & $(0.9535)$ & 0.1576 & $(0.4821)$ \\
\hline$N$ & $(2.3855)$ & 1.5815 & 39 & 0.6968 \\
\hline
\end{tabular}

Table 19. Business complexity and risk: new NPL / assets

Notes: The table reports the estimation of Equation 1, when using a two-stages least square estimation where the first-stage is estimated using Equation (2). The dependent variable is the new NPL to total assets ratio. Columns (1) to (4) correspond to the different measures of the independent variable on business complexity (Number of affiliates, Share of non-financial business types, Number of business types, HHI business types). The share of non-financial business types captures the percentage of the group's non-financial activities. The HHI for business types refers to the Herfindahl-Hirschman Index for business types and equals 0 when a group only operates in one business type. All the independent variables are lagged by one quarter. The sample period goes from 2014 to 2018. All specifications include time fixed effects. Two-stage least squares estimates with robust standard errors clustered at the bank level in parentheses. $* * *, * *$, and $*$ stand for statistical significance at $1 \%, 5 \%$, and $10 \%$, respectively. 


\begin{tabular}{|c|c|c|c|c|}
\hline & \multicolumn{4}{|c|}{ Business complexity indicator } \\
\hline & $\begin{array}{c}\text { Number of affiliates } \\
\text { (1) }\end{array}$ & $\begin{array}{c}\text { Share of non-financial } \\
\text { business types } \\
(2)\end{array}$ & $\begin{array}{c}\text { Number of business } \\
\text { types } \\
\text { (3) }\end{array}$ & $\begin{array}{c}\text { HHI business types } \\
\text { (4) }\end{array}$ \\
\hline Business complexity & $\begin{array}{c}0.0086 \\
(0.0264)\end{array}$ & $\begin{array}{c}-0.9431 \\
(0.7375)\end{array}$ & $\begin{array}{c}0.0950 \\
(0.2839)\end{array}$ & $\begin{array}{c}0.1506 \\
(0.5580)\end{array}$ \\
\hline Loans / assets & $\begin{array}{c}-0.0034 \\
(0.0067)\end{array}$ & $\begin{array}{c}-0.0023 \\
(0.0019)\end{array}$ & $\begin{array}{l}-0.0016 \\
(0.0018)\end{array}$ & $\begin{array}{c}-0.0033 \\
(0.0025)\end{array}$ \\
\hline ROA & $\begin{array}{c}0.0015 \\
(0.1843)\end{array}$ & $\begin{array}{c}-0.0402 \\
(0.0344)\end{array}$ & $\begin{array}{c}-0.0582 \\
(0.0409)\end{array}$ & $\begin{array}{l}-0.0638 \\
(0.0460)\end{array}$ \\
\hline Cost-to-income & $\begin{array}{c}0.0007 \\
(0.0113)\end{array}$ & $\begin{array}{c}0.0002 \\
(0.0015)\end{array}$ & $\begin{array}{l}-0.0028^{*} \\
(0.0028)\end{array}$ & $\begin{array}{c}-0.0019 \\
(0.0017)\end{array}$ \\
\hline Tier 1 ratio & $\begin{array}{l}-0.0086 \\
(0.0277)\end{array}$ & $\begin{array}{c}0.0048 \\
(0.0038)\end{array}$ & $\begin{array}{l}-0.0059 \\
(0.0186)\end{array}$ & $\begin{array}{l}-0.0026 \\
(0.0067)\end{array}$ \\
\hline In Assets & $\begin{array}{l}-0.1011 \\
(0.1428)\end{array}$ & $\begin{array}{l}0.0892^{* *} \\
(0.0397)\end{array}$ & $\begin{array}{l}-0.1163 \\
(0.1983)\end{array}$ & $\begin{array}{l}-0.0270 \\
(0.0203)\end{array}$ \\
\hline First-stage F-stat & 0.1605 & 1.5815 & 0.1576 & 0.6968 \\
\hline$N$ & 39 & 29 & 35 & 39 \\
\hline
\end{tabular}

Table 20. Business complexity and risk: risk-weighted assets to total assets

Notes: The table reports the estimation of Equation 1, when using a two-stages least square estimation where the first-stage is estimated using Equation (2). The dependent variable is the ratio of risk-weighted assets to total assets. Columns (1) to (4) correspond to the different measures of the independent variable on business complexity (Number of affiliates, Share of non-financial business types, Number of business types, HHI business types). The share of non-financial business types captures the percentage of the group's non-financial activities. The HHI for business types refers to the Herfindahl-Hirschman Index for business types and equals 0 when a group only operates in one business type. All the independent variables are lagged by one quarter. The sample period goes from 2014 to 2018. All specifications include time fixed effects. Two-stage least squares estimates with robust standard errors clustered at the bank level in parentheses. $* * *, * *$, and $*$ stand for statistical significance at $1 \%, 5 \%$, and $10 \%$, respectively. 


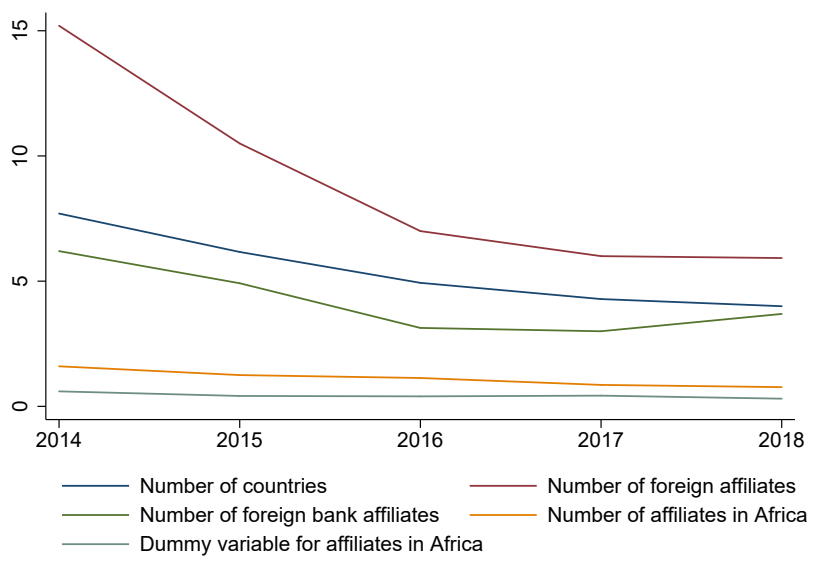

Figure 1: Geographical complexity indicators

Notes: The number of countries counts the countries in which each banking group operates. The number of foreign affiliates considers all branches and subsidiaries abroad, while the number of foreign bank affiliates considers only foreign branches and subsidiaries registered as banks. The number of affiliates (in Africa) counts all affiliates (in Africa).

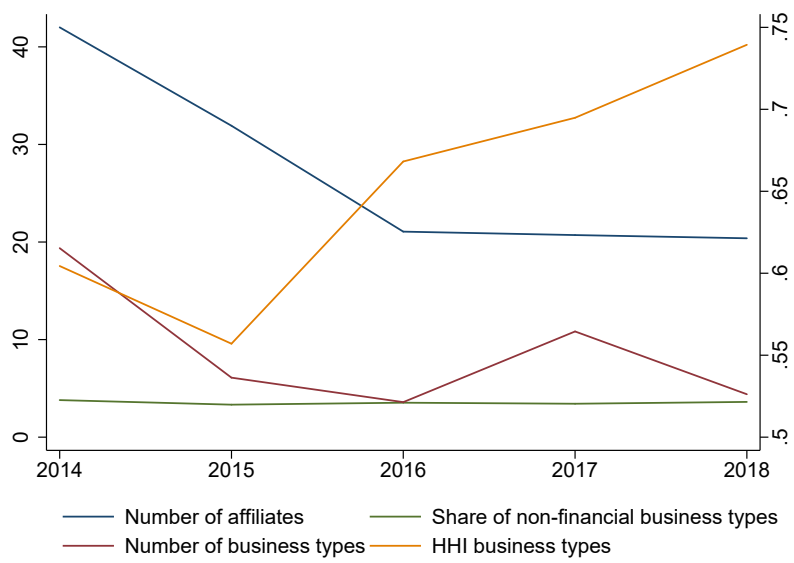

Figure 2: Structural complexity indicators

Notes: The share of non-financial business types captures the percentage of the group's non-financial activities. The HHI for business types refers to the Herfindahl-Hirschman Index for business types and equals 0 when a group only operates in one business type (left-hand scale). 


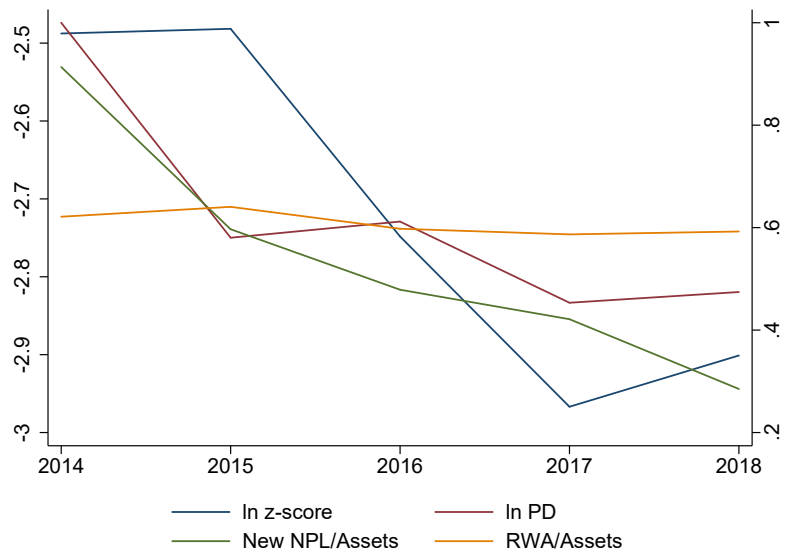

Figure 3: Risk-taking indicators

Notes: The In z-score is computed as the logarithm of the inverse of the average return on assets in a given period plus the equity to assets ratio of the bank, divided by the standard deviation of the return on assets in the last 8 quarters. Ln PD is computed as the logarithm of the average default probability of loans granted to firms by each bank, using the output of a firm-level credit scoring model (Antunes et al., 2016). New NPL / Assets is the flow of non-performing loans over total assets (right-hand scale). RWA / Assets is the ratio between risk-weighted assets and total assets (right-hand scale). 


\section{Working Papers}

\section{7}

1|17 The diffusion of knowledge via managers' mobility

Giordano Mion | Luca David Opromolla | Alessandro Sforza

2|17 Upward nominal wage rigidity

Paulo Guimarães | Fernando Martins | Pedro Portugal

3|17 Zooming the ins and outs of the U.S. unemployment

Pedro Portugal | António Rua

4|17 Labor market imperfections and the firm's wage setting policy

Sónia Félix | Pedro Portugal

5|17 International banking and cross-border effects of regulation: lessons from Portugal

Diana Bonfim | Sónia Costa

6|17 Disentangling the channels from birthdate to educational attainment

Luís Martins | Manuel Coutinho Pereira

7|17 Who's who in global value chains? A weighted network approach

João Amador | Sónia Cabral | Rossana Mastrandrea | Franco Ruzzenenti

8|17 Lending relationships and the real economy: evidence in the context of the euro area sovereign debt crisis

Luciana Barbosa
9|17 Impact of uncertainty measures on the Portuguese economy

Cristina Manteu | Sara Serra

10|17 Modelling currency demand in a small open economy within a monetary union

António Rua

11|17 Boom, slump, sudden stops, recovery, and policy options. Portugal and the Euro Olivier Blanchard | Pedro Portugal

12|17 Inefficiency distribution of the European Banking System

João Oliveira

13|17 Banks' liquidity management and systemic risk

Luca G. Deidda | Ettore Panetti

14|17 Entrepreneurial risk and diversification through trade

Federico Esposito

15|17 The portuguese post-2008 period: a narrative from an estimated DSGE model

Paulo Júlio | José R. Maria

16|17 A theory of government bailouts in a heterogeneous banking system

Filomena Garcia | Ettore Panetti

17|17 Goods and factor market integration: a quantitative assessment of the EU enlargement FLorenzo Caliendo | Luca David Opromolla | Fernando Parro | Alessandro Sforza 


\section{8}

1|18 Calibration and the estimation of macroeconomic models

Nikolay Iskrev

2|18 Are asset price data informative about news shocks? A DSGE perspective

Nikolay Iskrey

3|18 Sub-optimality of the friedman rule with distorting taxes

Bernardino Adão | André C. Silva

4|18 The effect of firm cash holdings on monetary policy

Bernardino Adão | André C. Silva

5|18 The returns to schooling unveiled Ana Rute Cardoso | Paulo Guimarães | Pedro Portugal | Hugo Reis

$6 \mid 18$ Real effects of financial distress: the role of heterogeneity

Francisco Buera | Sudipto Karmakar

7|18 Did recent reforms facilitate EU labour market adjustment? Firm level evidence Mario Izquierdo | Theodora Kosma | Ana Lamo | Fernando Martins | Simon Savsek

$8 \mid 18$ Flexible wage components as a source of wage adaptability to shocks: evidence from European firms, 2010-2013

Jan Babecký | Clémence Berson | Ludmila Fadejeva | Ana Lamo | Petra Marotzke | Fernando Martins | Pawel Strzelecki

9|18 The effects of official and unofficial information on tax compliance

Filomena Garcia | Luca David Opromolla Andrea Vezulli | Rafael Marques
10|18 International trade in services: evidence for portuguese firms

João Amador | Sónia Cabral | Birgitte Ringstad

11|18 Fear the walking dead: zombie firms, spillovers and exit barriers

Ana Fontoura Gouveia | Christian Osterhold

12|18 Collateral Damage? Labour Market Effects of Competing with China - at Home and Abroad

Sónia Cabral | Pedro S. Martins | João Pereira dos Santos | Mariana Tavares

13|18 An integrated financial amplifier: The role of defaulted loans and occasionally binding constraints in output fluctuations

Paulo Júlio | José R. Maria

14|18 Structural Changes in the Duration of Bull Markets and Business Cycle Dynamics

João Cruz | João Nicolau | Paulo M.M. Rodrigues

15|18 Cross-border spillovers of monetary policy: what changes during a financial crisis?

Luciana Barbosa | Diana Bonfim | Sónia Costa | Mary Everett

16|18 When losses turn into loans: the cost of undercapitalized banks

Laura Blattner | Luísa Farinha | Francisca Rebelo

17|18 Testing the fractionally integrated hypothesis using M estimation: With an application to stock market volatility

Matei Demetrescu | Paulo M. M. Rodrigues | Antonio Rubia 
18|18 Every cloud has a silver lining: Micro-level evidence on the cleansing effects of the Portuguese financial crisis

Daniel A. Dias | Carlos Robalo Marques

19|18 To ask or not to ask? Collateral versus screening in lending relationships

Hans Degryse | Artashes Karapetyan | Sudipto Karmakar

$20 \mid 18$ Thirty years of economic growth in Africa João Amador | António R. dos Santos

21|18 CEO performance in severe crises: the role of newcomers

Sharmin Sazedj | João Amador | José Tavares

22|18 A general equilibrium theory of occupational choice under optimistic beliefs about entrepreneurial ability Michele Dell'Era | Luca David Opromolla | Luís Santos-Pinto
23|18 Exploring the implications of different loanto-value macroprudential policy designs Rita Basto | Sandra Gomes | Diana Lima

24|18 Bank shocks and firm performance: new evidence from the sovereign debt crisis Luísa Farinha | Marina-Eliza Spaliara | Serafem Tsoukas

25|18 Bank credit allocation and productivity: stylised facts for Portugal Nuno Azevedo | Márcio Mateus | Álvaro Pina

26|18 Does domestic demand matter for firms' exports?

Paulo Soares Esteves | Miguel Portela | António Rua

27|18 Credit Subsidies Isabel Correia | Fiorella De Fiore | Pedro Teles | Oreste Tristani 


\section{9}

1|19 The transmission of unconventional monetary policy to bank credit supply: evidence from the TLTRO

António Afonso | Joana Sousa-Leite

2|19 How responsive are wages to demand within the firm? Evidence from idiosyncratic export demand shocks

Andrew Garin | Filipe Silvério

3|19 Vocational high school graduate wage gap: the role of cognitive skills and firms Joop Hartog | Pedro Raposo | Hugo Reis

4|19 What is the Impact of Increased Business Competition?

Sónia Félix | Chiara Maggi

5|19 Modelling the Demand for Euro Banknotes António Rua

6|19 Testing for Episodic Predictability in Stock Returns

Matei Demetrescu | Iliyan Georgiev Paulo M. M. Rodrigues | A. M. Robert Taylor

7|19 The new ESCB methodology for the calculation of cyclically adjusted budget balances: an application to the Portuguese case Cláudia Braz | Maria Manuel Campos Sharmin Sazed

8|19 Into the heterogeneities in the Portuguese labour market: an empirical assessment Fernando Martins | Domingos Seward

9|19 A reexamination of inflation persistence dynamics in OECD countries: A new approach

Gabriel Zsurkis | João Nicolau | Paulo M. M. Rodrigues
10|19 Euro area fiscal policy changes: stylised features of the past two decades Cláudia Braz | Nicolas Carnots

11|19 The Neutrality of Nominal Rates: How Long is the Long Run?

João Valle e Azevedo | João Ritto | Pedro Teles

12|19 Testing for breaks in the cointegrating relationship: on the stability of government bond markets' equilibrium

Paulo M. M. Rodrigues | Philipp Sibbertsen Michelle Voges

13|19 Monthly Forecasting of GDP with Mixed Frequency MultivariateSingular Spectrum Analysis

Hossein Hassani | António Rua | Emmanuel Sirimal Silva | Dimitrios Thomakos

14|19 ECB, BoE and Fed Monetary-Policy announcements: price and volume effects on European securities markets

Eurico Ferreira | Ana Paula Serra

15|19 The financial channels of labor rigidities: evidence from Portugal

Edoardo M. Acabbi | Ettore Panetti | Alessandro Sforza

16|19 Sovereign exposures in the Portuguese banking system: determinants and dynamics

Maria Manuel Campos | Ana Rita Mateus | Álvaro Pina

17|19 Time vs. Risk Preferences, Bank Liquidity Provision and Financial Fragility

Ettore Panetti 
18|19 Trends and cycles under changing economic conditions

Cláudia Duarte | José R. Maria | Sharmin Sazedj

19|19 Bank funding and the survival of start-ups Luísa Farinha | Sónia Félix | João A. C. Santos

\section{0}

1|20 On-site inspecting zombie lending Diana Bonfim | Geraldo Cerqueiro | Hans Degryse | Steven Ongena

2|20 Labor earnings dynamics in a developing economy with a large informal sector

Diego B. P. Gomes | Felipe S. Iachan | Cezar Santos

3|20 Endogenous growth and monetary policy: how do interest-rate feedback rules shape nominal and real transitional dynamics?

Pedro Mazeda Gil | Gustavo Iglésias

4|20 Types of International Traders and the Network of Capital Participations

João Amador | Sónia Cabral | Birgitte Ringstad

5|20 Forecasting tourism with targeted predictors in a data-rich environment

Nuno Lourenço | Carlos Melo Gouveia | António Rua

6|20 The expected time to cross a threshold and its determinants: A simple and flexible framework

Gabriel Zsurkis | João Nicolau | Paulo M. M. Rodrigues
20|19 From micro to macro: a note on the analysis of aggregate productivity dynamics using firm-level data Daniel A. Dias | Carlos Robalo Marques

21|19 Tighter credit and consumer bankruptcy insurance

António Antunes | Tiago Cavalcanti | Caterina Mendicino | Marcel Peruffo | Anne Villamil

7|20 A non-hierarchical dynamic factor model for three-way data

Francisco Dias | Maximiano Pinheiro | António Rua

8|20 Measuring wage inequality under right censoring

João Nicolau | Pedro Raposo | Paulo M. M. Rodrigues

9|20 Intergenerational wealth inequality: the role of demographics

António Antunes | Valerio Ercolani

10|20 Banks' complexity and risk: agency problems and diversification benefits Diana Bonfim | Sónia Felix 
